\title{
The role of irrigation in determining the global land use impacts of biofuels
}

\author{
Farzad Taheripour*, Thomas W Hertel and Jing Liu
}

\begin{abstract}
Background: Recent studies have evaluated the land use consequences of biofuel programs and the associated carbon fluxes. However, all of these studies have effectively ignored the distinction between rainfed and irrigated lands and neglected the facts that irrigated croplands typically have much higher yields than their rainfed counterparts in the same region and that expansion in irrigated crops are limited in some regions due to water scarcity and irrigation constraint. This paper shows that these omissions introduce systematic biases in the measurement of biofuel-induced land use change emissions.

Methods: A new computable general equilibrium model which distinguishes irrigated and rainfed agriculture is developed. The new model is an enhanced version of the publicly available Global Trade Analysis Project model with Biofuels (GTAP-BIO) which has been widely used in this field frequently. To distinguish irrigated and rainfed agriculture, the biophysical component of the GTAP-BIO model is extensively modified using the most recent published data in this area. The economic component of the model is also modified to handle the distinction between irrigated and rainfed agriculture.
\end{abstract}

Results: We find that ignoring the irrigated-rainfed distinction modestly underestimates global land use change, but results in sharply different geographic patterns of cropland expansion, with stronger rainfed expansion in more carbon-rich environments. This points to a significant underestimate of land use emissions in earlier studies.

Conclusions: To provide more accurate estimates of biofuel-induced land use emissions, it is critical to incorporate the role of irrigation in crop production, taking into account the fact that expansion in irrigation is constrained in some regions across the world.

Keywords: Irrigated agriculture, Rainfed agriculture, Irrigation constraints, Indirect land use change, Computational general equilibrium, GTAP-BIO

\section{Background}

Previous research into the global land use impacts of biofuels has assumed that cropland area could expand in most regions of the world. Such estimated expansion into more carbon-rich land cover such as grasslands or forest is the focus of recent research into the contributions of indirect land use changes (ILUC) to the GHG impacts of biofuels. Many studies have examined the global land use consequences of biofuel production [1-7]. However, all of these studies have ignored the role of irrigation. We find that this omission introduces systematic biases in the measurement of the size and

* Correspondence: tfarzad@purdue.edu

Department of Agricultural Economics, Purdue University, 403 West State St, West Lafayette, IN 47907-2056, USA

\section{Springer}

pattern of global land use changes and therefore the land use emissions due to production of biofuels.

Irrigated croplands typically have much higher yields than their rainfed counterparts in the same country/ agro-ecological zone (AEZ) [8]. Thus, the question of whether expansion of global cropland cover involves irrigated or rainfed lands makes a significant difference in terms of how much new land will be required to provide the additional production called for in the presence of biofuels. If the new lands are irrigated and therefore have higher yields than rainfed lands in the same AEZ, then less land conversion will be required. However, if expansion of irrigated area is constrained, either due to insufficient water or due to insufficient pumping capacity, then it is likely that more cropland area will be 
required to meet the additional global demand induced by ethanol production.

A recent report by McKinsey \& Co. [9], offers an assessment of water availability over the coming two decades, drawing heavily on the IFPRI water model [10]. They start at the river basin level and calculate water demand based on current technology and expected growth in agricultural and industrial output as well as population. In the absence of efficiency gains, they estimate that water demand will exceed existing sustainable, reliable water supply by $40 \%$ in 2030 . McKinsey \& Co. estimate that one-third of the world's population in 2030 will live in basins where the projected gap is greater than $50 \%$ [9]. This finding is reinforced by the analysis of global water use in agriculture by Rockström et al. [11] who estimate a deficit of $2,500 \mathrm{~km}^{3}$ of water per year by 2030 in the absence of rainfed area expansion. In summary, it appears that water for agricultural irrigation will become much more expensive in the future - no doubt spurring considerable efficiency gains, but also raising the cost of production and therefore limiting the amount of land on which irrigated crops can be economically grown.

In addition to leading to an understatement of global area requirements, omitting explicit analysis of irrigation and associated constraints is likely to overstate the potential for expansion of croplands in dry (currently irrigated) regions with lower land use emission factors (less aboveground carbon). In the presence of irrigation constraints, the distribution of land use changes induced by biofuel production will shift towards areas where expansion of rainfed agriculture is possible. These regions tend to be more carbon rich and therefore exhibit higher ILUC emission factors. Therefore, earlier models which ignore the role of irrigation in crop expansion tend to underestimate the ILUC emissions due to biofuel expansion. In this paper, we explore the impacts of water constraints on the ILUC emission estimates due to US ethanol production.

To accomplish this task, given the fact that a large-scale expansion in biofuels affects a broad range of economic activities at a global scale, a global computational general equilibrium (CGE) model is developed building on the recent work of Taheripour et al. [7] (henceforth THT). Those authors build on the Global Trade Analysis Project model with Biofuels (GTAP-BIO) database [12] in order to develop a global CGE model which handles production, consumption, and trade of biofuels along with other economic activities and is capable of tracing the land use impacts of expansion in biofuels. Similar to most other models used for this purpose, the THT analysis ignores the role of irrigation. In this paper, we remedy this previous major limitation and find that the consequences for land-based emissions are significant.

We begin by modifying the GTAP database to distinguish irrigated and rainfed agriculture. To carry out this important task, we follow the pioneering work of Portmann et al. [8] (henceforth PSD) who developed a land use database which provides data on harvested area and crop production by 29 crops and 160 countries/regions at the $5 \times 5$ arc minute grid cell level. These spatially disaggregated data are aggregated to the level of 18 GTAP-AEZs while maintaining the distinction between irrigated and rainfed crops. Using the information obtained from this data set, all crop industries presented in the v.6 GTAP database are broken into irrigated and rainfed categories, as outlined later in this paper.

In the second step, the GTAP-BIO-AEZ model used in THT is extended and modified to handle production, consumption, and trade of irrigated and rainfed crops. To accomplish this imperative task, all components of the GTAP-BIO-AEZ model including production, demand, and supply functions as well as market clearing conditions are revisited. In this revised model, it is assumed that, for each crop, irrigated and rainfed industries produce the same commodity (e.g., wheat) which enters the market and sells for the same price. This homogeneity assumption means that it is possible for irrigated production of any given crop to be completely eliminated if competition for irrigated land is sufficiently intense in a given region. This is an important distinction from the GTAP-based modeling approach of Calzadilla et al. [13] which assumes that irrigated land is simply one of many inputs into a single national production function.

This entirely revised and enhanced model is used to conduct a series of experiments which permit us to revisit the global land use impacts of biofuel expansion, comparing the findings to those previously obtained by ignoring the distinction between irrigated and rainfed agriculture. The first experiment assumes that there is no water constraint across the world and that irrigated area can be expanded wherever economic incentives dictate, in response to expanded US ethanol production. In the second experiment, we impose a set of water scarcity constraints, defined based on information from the International Water Management Institute (IWMI). These constraints prevent expansion of irrigated area in regions where there is physical water scarcity (as opposed to insufficient capacity or other economically driven constraints). The ILUC results associated with these two models (constrained and unconstrained) are found to bracket the results generated when failing to distinguish rainfed and irrigated agriculture, as has been the case with previous studies.

Land use changes and their consequent emissions induced by crop expansion due to biofuel production have proven to be a controversial topic, resulting in a rapidly proliferating literature. The early papers suggested that biofuel production could have extraordinary land use 
implications [2,14-16]. For example, Searchinger et al. [2] provided the first peer-reviewed estimate for the ILUC (about 0.193 ha of new cropland area per 1,000 l of ethanol capacity). Those authors used a partial equilibrium modeling framework (FAPRI) to assess the ILUC due to the US ethanol program. However, the more recent studies find that the early estimates have overstated the land use implications of US ethanol production [5,6,17-21]. For example, Hertel et al. [17] using a general equilibrium model showed that full accounting for market-mediated price responses to ethanol production, as well as the geography of world trade, contributed to significant reductions in estimated ILUC impacts. Those authors estimated that the ILUC for the US ethanol program is about $0.077 \mathrm{ha} / 1,000 \mathrm{l}$ of ethanol.

Research studies in this area have highlighted and discussed key factors in determining the land use impacts of biofuels and their geographical distributions. Several papers discussed the importance of yield response to crop prices and extensive margins $[2,6,17,22,23]$, the market-mediated factors which affect the land use impacts of biofuels $[4,15,17,18,21]$, and the role of international trade and its importance in determining the geographical distribution of land use changes $[2-4,18,21,24]$. The interactions between livestock and biofuel industries and the role of biofuel by-products are another important dimension of this problem and are the focal point of the THT model upon which the current analysis is built. The model provided by these authors is not the latest version of GTAP-BIO, but it has almost all modifications which are confirmed through a peer-reviewing process.

Intimately related to these estimates of land use changes are the associated implications for emissions induced by land cover change coming from increased biofuel production. Wicke et al. [25] compare these estimates and find that the most recent estimates for the land use emissions are significantly lower than the earlier estimates. For example, land use emissions due to the US ethanol program have followed a downward path from more than $100 \mathrm{~g} / \mathrm{MJ}$ [2] to less than $14.5 \mathrm{~g} / \mathrm{MJ}$ [6]. Most of these reductions have resulted from better measurement of the various margins of biophysical and economic response to increased biofuel production. However, all of these studies have ignored the role of irrigation constraints in their analyses. Indeed, despite the extensive work to date seeking to better understand the land use implications of biofuels, no attempt has been made to examine the role of irrigation in biofuel-induced cropland expansion. Nevertheless, some studies [26-28] have examined water implications of producing biofuels at regional and global levels.

This paper expands the capability of the GTAP modeling framework, which has been extensively used in land use assessments of biofuels, to disaggregate irrigation activities. We find that, in contrast to the recent trend in such studies, incorporating explicit modeling of irrigation, and associated constraints, significantly raises the land-based emissions associated with biofuel expansion.

\section{Methods}

Our modeling framework is built on the GTAP-BIO-AEZ model, an extended version of the GTAP standard model [29]. The GTAP-BIO-AEZ model is designed, modified, and frequently used in policy arena to assess the economic and environmental consequences of biofuel production and policy. This model traces production, consumption, and trade of goods and services including biofuels and their by-products at a global scale. The GTAP-BIO-AEZ model links economic and biophysical information through the market for land where agricultural, forestry, and livestock activities compete for land.

Linking economic and biophysical information through the land market is a common approach among many CGE and partial equilibrium (PE) models [30]. Prominent PE models used to analyze food, agriculture, trade, and biofuel policies include the following: IMPACT [31], WATSIM [32], FASOM [33,34], and MAgPIE which was developed by Lotze-Campen et al. [35] and recently used by Schmitz et al. [36] to analyze impact of world food trade on greenhouse gas emissions and land use changes. The latter model captures the spatial aspects of land use changes at a gridded level. However, all of the PE models ignore the forward and backward links between agricultural activities and the rest of the economy.

In contrast, the CGE models, and in particular the GTAP-BIO-AEZ, use biophysical information at the level of an agro-ecological zone, but take into account interactions between agricultural activities and the rest of the economy. In each region of this model, there may be as many as 18 AEZs which differ in length of growing period (six categories of 60-day growing period intervals) and climatic zones (three categories of tropical, temperate, and boreal). The length of growing period depends on temperature, precipitation, soil characteristics, and topography. The productivity of each AEZ under alternative crops, forestry, and livestock activities is based on current yields in that AEZ, although these yields are permitted to change depending on relative prices (intensification). This paper enhances the biophysical component of the GTAP-BIO-AEZ model by distinguishing between irrigated and rainfed cropping activities at the AEZ level using the biophysical data developed by PSD [8] and used in several studies including the recent study by Schmitz et al. [36] which focuses on food trade.

\section{Database construction}

To incorporate crop industries by irrigation type (i.e., irrigated and rainfed) into the GTAP-BIO-AEZ database, 
we rely on the SAGE database documented in Monfreda et al. [37] and the pioneering work done by PSD [8] who developed a database which provides data on harvested area and yield by irrigation type for 29 groups of crops and 160 countries/regions at the $5 \times 5$ arc minute grid cell level. We achieve this split through two steps which are explained in sequence below.

\section{Determining harvested area and crop production by irrigation type}

We began with the PSD data at the grid cell level and computed production by irrigation type and crop as the product of harvested area and yield. Then we aggregated PSD gridded harvested area and crop production up to country by AEZ and crop to match the results with the GTAP aggregation scheme of the data set of Monfreda et al. [37]. The GTAP data set aggregates crops into eight categories, as presented in the 'Appendix'. In the next step, as explained in the 'Appendix', we 'shared out' the quantity produced and area harvested in the SAGE database into irrigated and rainfed components using their corresponding shares obtained from the PDS data set by country, AEZ, and crop. Finally, the new data set is aggregated into 19 regions by AEZ according to the regional aggregation level used in this paper. These 19 regions and their members are shown in the 'Appendix'.

The new data set is summarized and described from different perspectives in the 'Appendix'. In this newly constructed database, about $23 \%$ of the global harvested area is irrigated, while global irrigated lands account for about $38 \%$ of global agricultural outputs. These figures which are in line with the corresponding global figures reported by the Food and Agricultural Organization of the United Nations, $23.4 \%$ and $44 \%$, respectively [38], indicate that irrigated lands are more productive versus rainfed lands. The global average yields for irrigated and rainfed areas are about 10.8 and 5.3 metric ton/ha. The 'Appendix' indicates that irrigated yields are usually higher than their rainfed counterparts as we consider more disaggregated data by region, crop, and AEZ. This 'Appendix' also indicates that India and China heavily rely on irrigated agriculture compared to other regions. However, their irrigated yields are, in general, lower than their corresponding figures in the USA and European Union. The 'Appendix' examines in detail the role of irrigation in crop production.

\section{Splitting the GTAP database}

The next step in constructing the irrigation-augmented model is to divide each and every crop activity in the GTAP database into two crop industries representing irrigated and rainfed production using the SplitCom program [39]. We establish the split process based on the following assumptions. First, we assume that the irrigated and rainfed products are homogeneous. By implication, the prices of rainfed wheat and irrigated wheat are the same, similarly for other crops. Second, we assume that the rainfed and irrigated crop producers pay the same price for a given input. This means that, for example, the price of seed is the same for both producers. Third, we assume that the input-output ratio is the same for both rainfed and irrigated production. This means that the same amount of fertilizer is required to produce a ton of wheat, regardless of whether it is irrigated or rainfed. When combined with the equal output and input price assumptions, this implies that the cost shares are the same for each input used in the two industries. For example, the cost share of labor in the irrigated wheat industry must be the same as the cost share of labor in the rainfed wheat industry; for a formal proof, see the last section of the 'Appendix'. Since the value of output per hectare will be higher in irrigated land (due to higher yields) and since the share of this higher value going to the land is the same as for rainfed land, then the returns to irrigated land will also be higher; for a formal proof, see the 'Appendix'. In this paper, water is an implicit input embodied in irrigated land. Hence, the higher revenues due to irrigation will be captured in the land rent. These assumptions provide a theoretical basis for using the SplitCom utility [39] to divide each and every crop industry of GTAP into two distinct industries of irrigated and rainfed production. The SplitCom program requires input information on the shares of irrigated and rainfed industries in the sales, costs, and trade items of each crop industry to carry out the industry-splitting process in each region. Accordingly, we calculated the shares of irrigated and rainfed quantities of production of each crop in the total production of that crop prior to running SplitCom. Note that these implemented modifications are made at the most disaggregated level of the GTAP database; thereafter, results are aggregated into the 19-region level used in this paper. The obtained database from this process is available upon request from the authors.

\section{Modification of the GTAP-BIO model}

The standard GTAP modeling framework uses a one-toone relationship between industries and commodities. This means that, in the standard framework, each industry produces only one commodity and each commodity is produced only by one industry. The GTAP-BIO modeling framework deviates from this tradition and introduces multiproduct sectors in order to handle biofuel byproducts [5]. In this paper, we extend the GTAP-BIO model to the case where the same product is produced by two different industries, one irrigated and one rainfed. This means that it is possible for irrigated production of any given crop to be completely eliminated if competition for irrigation is sufficiently intense in a given region since 


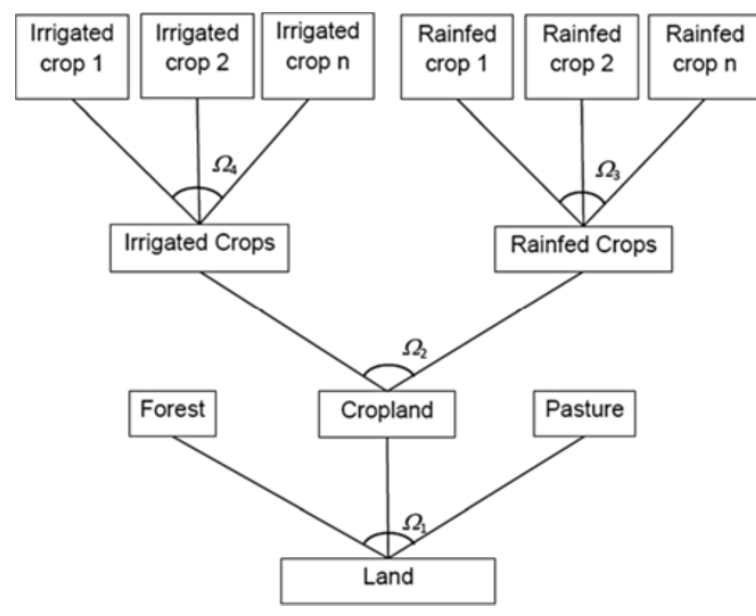

Figure 1 Modified land supply tree.

demand for the regionally differentiated crop can be fulfilled instead from rainfed production. The revised model main equations are provided in the 'Appendix'.

In addition, we redesigned the land supply function used in the GTAP model to account for irrigated land. As shown in Figure 1, the lower level of the land supply tree allocates land cover among forest, pastureland, and cropland categories. The second level of the new structure allocates cropland between irrigated and rainfed cropping activities. Finally, the top level of the new tree governs the supplies of irrigated and rainfed areas among the irrigated and rainfed cropping activities, separately. In addition to the above changes, we made the necessary changes in the GTAP code to support production of crops by irrigation type.

\section{Experimental design}

To analyze the role of irrigation in determining the global land use consequences of biofuels, we undertake three experiments. In the first experiment, we use the modeling framework developed in THT to assess the land use impacts of ethanol production. This experiment reflects the current state of the art in which authors do not distinguish between irrigated and rainfed lands. Henceforth, we refer to this case as noirrigation experiment.

The second and third experiments are built based on the new model developed in this paper. In the second experiment, it is assumed that there is no water constraint anywhere in the world; if so desired, irrigated land can be expanded as long as it is profitable. Henceforth, we refer to this case as unconstrained irrigation experiment.

Finally, in the third simulation, we limit the expansion of irrigation in those areas where water supply is limited and cannot be expanded. To accomplish this task, we rely on the data provided by IWMI. These data were taken from Smakhtin [40]. This institute provided a map which shows water scarcity across the world. The map distinguishes three types of water scarcity. The first two groups represent the areas which are currently facing physical water scarcity or approaching this constraint. The third category shows the areas which are facing economic constraints to use water resources (Figure 2). In this paper, we collapsed the first two types of water scarcity to determine the regions which are facing water limits, and hence, we assume that irrigation cannot be expanded in those areas. Since economic constraints are built in the GTAP database, we do not impose any priori restriction on the expansion of irrigation in the areas indicated as being constrained for economic reasons. Henceforth, we refer to this case as constrained irrigation experiment.

In addition to these three main experiments, following Hertel et al. [17], we developed an additional experiment which assumes that food consumption is fixed everywhere in the presence of irrigation constraints. By comparison with our baseline simulation, this experiment allows us to assess the land use consequences of reduced food consumption in the wake of ethanol production. The results obtained from this experiment are compared with the results of the constrained irrigation experiment in the 'Endnotes'.

In all experiments developed in this paper, we simulated the land use consequences of an increase in US ethanol production from its level in 2001 (about 6.7 billion liters) to 56.78 billion liters, which is the mandated level of ethanol for 2015. Following Hertel et al. [17], in these experiments, we only shocked US ethanol to isolate impacts of US ethanol production from other factors which shape the world economy. In these experiments, we also use the same elasticities and parameters used in THT. The only exception is related to the newly introduced land transformation elasticity between the irrigated and rainfed croplands in the land supply tree. To represent a fluid movement between the irrigated and rainfed croplands in response to economic incentives, we set $\Omega_{2}=10$. This high value of the land transformation elasticity permits land conversion from rainfed areas to irrigated areas if the latter become relatively more profitable in the wake of increased ethanol production. However, in the context of our constrained experiment, such expansion of irrigated area is not permitted in regions where physical water scarcity is present.

\section{Results and discussions Land use changes}

Table 1 compares the regional land use changes obtained from the experiments defined in the previous section. This table indicates that as we move from the 


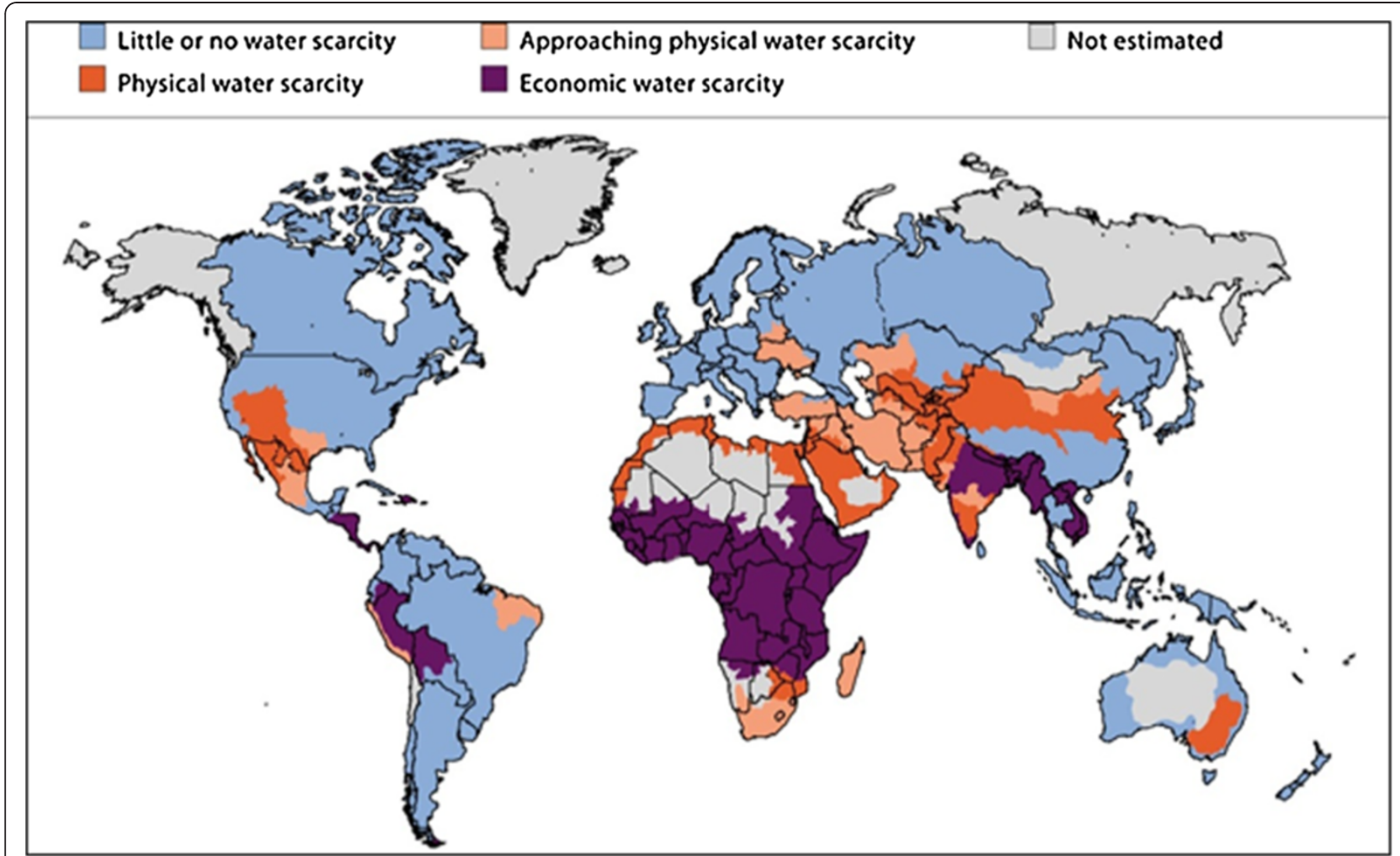

Figure 2 Global water scarcity. (Source: IWMI).

unconstrained case to the constrained case, the land use impacts of biofuels increase. An increase in the US ethanol production from its 2001 level to 56.78 billion liters requires about 3.75 million hectares of additional cropland when there is no water constraint. Under the constrained case, the magnitude of the land requirement increases to 4.4 million hectares. The land use requirement for the no-irrigation constraint case is about 4.2 million hectares and therefore falls in between the results for the unconstrained and constrained cases. The magnitudes of the land requirement per 1,000 l of ethanol for the unconstrained, no-irrigation, and constrained cases are about $0.074,0.085$, and 0.087 ha. These results confirm that earlier studies which mingled the irrigated and rainfed areas and ignored the fact that irrigated areas cannot be expanded in many regions across the world underestimate the land use impacts of US ethanol production by about $5.7 \%$. The results obtained from the unconstrained and constrained cases indicate that the imposition of realistic irrigation constraints increases the size of land requirement by $18 \%$.

The results also show that the presence of irrigation constraints alters the geographic pattern of land use change in the wake of the US ethanol expansion. For example, Table 1 indicates that the irrigation constraint significantly expands the shares of the US, Canadian, and Sub-Saharan African regions while reducing that for some Eastern European countries and a portion of former Soviet Union (included in E-Europe-RFSU).

The composition of land conversion also changes when we move from the unconstrained case to the constrained one. Since rainfed agriculture is more likely than irrigated agriculture to compete with forest, the constrained case shows greater conversion of forest compared to the unconstrained case globally (up from $28.9 \%$ in the unconstrained case to $31.5 \%$ in the constrained case, see Table 2). However, the share of forest in the USA does not vary significantly across these two cases. Table 2 indicates that the no-irrigation case significantly underestimates the share of forest in the US cropland expansion.

We now examine the distribution of changes in cropland by rainfed versus irrigated agriculture. Table 3 shows that in the unconstrained case, ethanol production increases mainly global irrigated areas by about 3.7 million hectares (about $98.6 \%$ of the total). In this experiment, regions such as the USA, EU27, China, and members of E-Europe-RFSU expand their irrigation areas while reducing their rainfed activities. On the other hand, in this experiment, some regions such as Brazil, Canada, and Sub-Saharan Africa increase their irrigated and rainfed areas together.

The irrigation constraint reduces the global irrigated areas from 3.7 million to 1.3 million hectares and 
Table 1 Irrigation constraint and land use changes due to US ethanol production (1,000 ha)

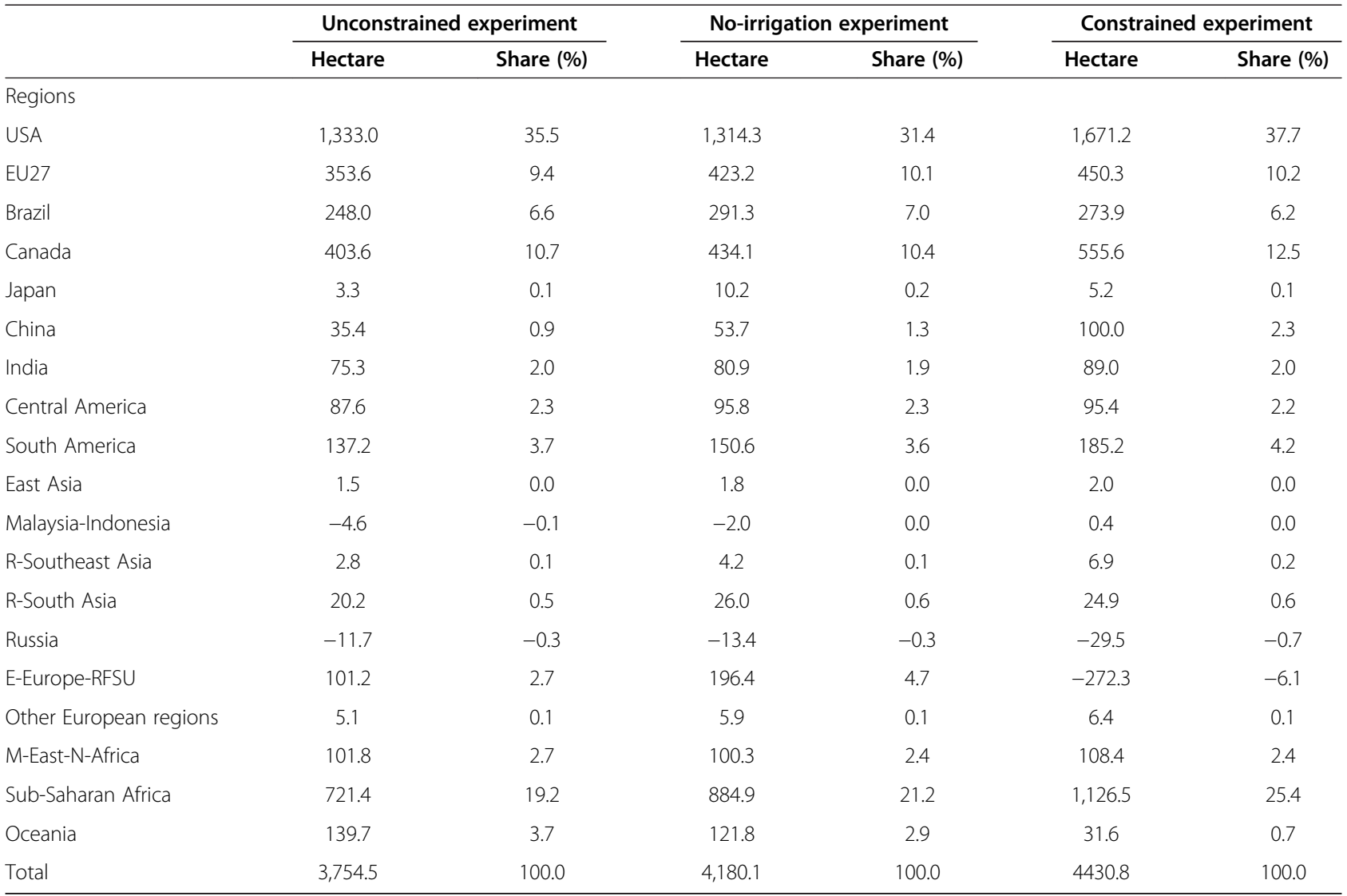

increases the global rainfed areas from a negligible magnitude to 3.2 million hectares. In the constrained case, the EU27 expands its irrigated areas by 1.1 million hectares. In this case, most of the regions mainly expand their rainfed areas.

While Tables 1, 2, and 3 show the overall land use impacts of ethanol production under alternative assumptions about the potential for irrigation expansion, the picture at the AEZ level is more complex. To examine the impacts of the irrigation constraint on the geographic pattern of land use within the USA, consider Table 4, which reports differences between the changes in the cropland areas of this region by AEZ obtained from the unconstrained and constrained cases. This table indicates that, when there is no irrigation constraint, the irrigated areas in AEZ7 and AEZ8 go up significantly in response to higher demand for corn. About $50 \%$ of US irrigated area resides in these two AEZs where the yield difference between irrigated and rainfed cropping activities is very high. Hence, when there

no irrigation constraint, ethanol production converts rainfed areas to irrigated areas in these two AEZs. On the other hand, as shown in Table 4, ethanol production leads to minor changes in irrigated areas in AEZ9, AEZ10, and AEZ11. These AEZs cover the Midwest of the USA where rainfed cropping activities are productive and irrigation contributes only modestly to yield increases. In general, expansion in corn demand increases corn supply at the cost of reduction in the production of

Table 2 Irrigation constraint and shares of forest and pasture in land use changes due to US ethanol production

\begin{tabular}{|c|c|c|c|c|c|c|}
\hline \multirow[t]{2}{*}{ Regions } & \multicolumn{2}{|c|}{ Unconstrained experiment } & \multicolumn{2}{|c|}{ No-irrigation experiment } & \multicolumn{2}{|c|}{ Constrained experiment } \\
\hline & Forest (\%) & Pasture (\%) & Forest (\%) & Pasture (\%) & Forest (\%) & Pasture (\%) \\
\hline USA & 51.0 & 49.0 & 39.5 & 60.5 & 51.1 & 48.9 \\
\hline $\mathrm{EU} 27$ & 64.4 & 35.6 & 65.0 & 35.0 & 64.3 & 35.7 \\
\hline Brazil & 27.5 & 72.5 & 24.9 & 75.1 & 19.8 & 80.2 \\
\hline Other regions & 6.0 & 94.0 & 6.4 & 93.6 & 9.8 & 90.2 \\
\hline World & 28.9 & 71.1 & 24.1 & 75.9 & 31.5 & 68.5 \\
\hline
\end{tabular}


Table 3 Irrigated and rainfed cropland changes due to US ethanol production $(1,000 \mathrm{ha})$

\begin{tabular}{|c|c|c|c|c|}
\hline & \multicolumn{2}{|c|}{ Unconstrained } & \multicolumn{2}{|c|}{ Constrained } \\
\hline & Irrigated & Rainfed & Irrigated & Rainfed \\
\hline \multicolumn{5}{|l|}{ Regions } \\
\hline USA & $2,166.5$ & -833.5 & 11.8 & $1,659.3$ \\
\hline EU27 & 828.6 & -475.0 & $1,094.8$ & -644.5 \\
\hline Brazil & 3.5 & 244.5 & 3.9 & 270.0 \\
\hline Canada & 6.3 & 397.2 & 6.4 & 549.3 \\
\hline Japan & 0.8 & 2.5 & 1.3 & 3.9 \\
\hline China & 167.0 & -131.5 & 62.5 & 37.5 \\
\hline India & 51.3 & 24.0 & 61.5 & 27.5 \\
\hline Central America & 1.7 & 85.9 & 4.4 & 91.0 \\
\hline South America & 0.9 & 136.2 & 4.7 & 180.6 \\
\hline East Asia & 0.2 & 1.3 & 0.2 & 1.8 \\
\hline Malaysia-Indonesia & -0.2 & -4.4 & 0.0 & 0.3 \\
\hline Rest of Southeast Asia & 0.2 & 2.6 & 0.6 & 6.3 \\
\hline Rest of South Asia & 3.6 & 16.6 & 1.3 & 23.6 \\
\hline Russia & 4.9 & -16.6 & 4.6 & -34.1 \\
\hline E-Europe-RFSU & 354.8 & -253.5 & 0.0 & -272.3 \\
\hline Other European regions & 0.1 & 5.1 & 0.1 & 6.3 \\
\hline M-East-N-Africa & 57.6 & 44.2 & 0.0 & 108.4 \\
\hline Sub-Saharan Africa & 54.9 & 666.4 & 4.1 & $1,122.5$ \\
\hline Oceania & -1.0 & 140.7 & 0.6 & 31.0 \\
\hline Total & $3,701.8$ & 52.7 & $1,262.6$ & $3,168.2$ \\
\hline
\end{tabular}

Obtained from unconstrained and constrained experiments.

other crops. When there is no irrigation constraint (unconstrained columns), the irrigated corn industry expands its production in areas where irrigation significantly contributes to production (i.e., AEZ7 and AEZ8). On the other hand, the rainfed corn industry mainly expands its activities in the Midwest where irrigation is not an issue.

When irrigation is constrained, the irrigated corn industry cannot expand its activities in the AEZs where irrigation is critical to production. On the other hand, in the rainfed AEZs, the profitability of irrigated agriculture does not rise as sharply as for rainfed production, and therefore, the irrigated area does not experience the same strong expansion. Instead, as shown in Table 4, it is the rainfed corn industry that expands most strongly in this area.

Figures 3, 4, 5, 6 report the change in cropland cover across the world owing to increased ethanol production in the USA for the unconstrained and constrained cases. In these maps, figures represent changes in irrigated and rainfed harvested areas at the region/AEZ level. These maps illustrate that the irrigation constraint significantly
Table 4 Changes in US cropland by AEZ due to US ethanol production ( $1,000 \mathrm{ha})$

\begin{tabular}{|c|c|c|c|c|c|c|}
\hline & \multicolumn{3}{|c|}{ Unconstrained } & \multicolumn{3}{|c|}{ Constrained } \\
\hline & Irrigated & Rainfed & Total & Irrigated & Rainfed & Total \\
\hline \multicolumn{7}{|l|}{$\overline{\mathrm{AEZ}}$} \\
\hline AEZ1 & 0.0 & 0.0 & 0.0 & 0.0 & 0.0 & 0.0 \\
\hline AEZ2 & 0.0 & 0.0 & 0.0 & 0.0 & 0.0 & 0.0 \\
\hline AEZ3 & 0.0 & 0.0 & 0.0 & 0.0 & 0.0 & 0.0 \\
\hline AEZ4 & 0.0 & 0.0 & 0.0 & 0.0 & 0.0 & 0.0 \\
\hline AEZ5 & 0.0 & 0.0 & 0.0 & 0.0 & 0.0 & 0.0 \\
\hline AEZ6 & 0.0 & 0.0 & 0.0 & 0.0 & 0.0 & 0.0 \\
\hline AEZ7 & $1,550.5$ & $-1,349.2$ & 201.3 & 0.0 & 291.7 & 291.7 \\
\hline AEZ8 & 580.6 & -449.9 & 130.7 & 0.0 & 183.7 & 183.7 \\
\hline AEZ9 & 0.7 & 49.1 & 49.8 & 0.9 & 58.6 & 59.4 \\
\hline AEZ10 & 8.6 & 469.8 & 478.4 & 9.9 & 541.3 & 551.2 \\
\hline AEZ11 & 8.6 & 334.5 & 343.1 & 10.1 & 390.6 & 400.7 \\
\hline AEZ12 & -6.5 & 125.7 & 119.2 & -9.0 & 176.6 & 167.6 \\
\hline AEZ13 & 24.2 & -18.4 & 5.8 & 0.0 & 11.6 & 11.6 \\
\hline AEZ14 & -0.3 & 4.6 & 4.3 & 0.0 & 4.7 & 4.7 \\
\hline AEZ15 & 0.0 & 0.3 & 0.4 & 0.0 & 0.6 & 0.6 \\
\hline AEZ16 & 0.0 & 0.0 & 0.0 & 0.0 & 0.0 & 0.0 \\
\hline AEZ17 & 0.0 & 0.0 & 0.0 & 0.0 & 0.0 & 0.0 \\
\hline AEZ18 & 0.0 & 0.0 & 0.0 & 0.0 & 0.0 & 0.0 \\
\hline Total & $2,166.5$ & -833.5 & $1,333.0$ & 11.8 & 1,659.3 & $1,671.2$ \\
\hline
\end{tabular}

Obtained from unconstrained and constrained experiments. The USA has no land in AEZ1 to AEZ6 and AEZ16 to AEZ18.

alters the geographical distribution of irrigated and rainfed areas across the world.

\section{Land use emissions}

To calculate land use emissions due to the US ethanol production for the cases developed in this paper, we rely on the land use emission factors reported for a 30-year time horizon by Plevin et al. [41]. These authors developed a model, augmented with a series of land use emission factors, which gauge carbon fluxes due to land use changes induced by biofuel production at the AEZ level at a global scale. Figures 7 and 8 report the land use emission factors for the conversion of forest and pasture to cropland. These maps show that the land use emission factors vary both geographically and by land type. For example, Figure 7 shows that the Malaysian and Indonesian forest areas have very large carbon fluxes, whereas the emissions associated with land conversion in the dry regions in Central Asia are quite low. The maps also indicate that the carbon fluxes are very different across AEZs within each region. For example, the forest emission factor of US AEZ7 (which covers a large area in the western USA) is about $469 \mathrm{Mg} \mathrm{CO} /$ ha. The corresponding forest emission factors for the US AEZ9, 


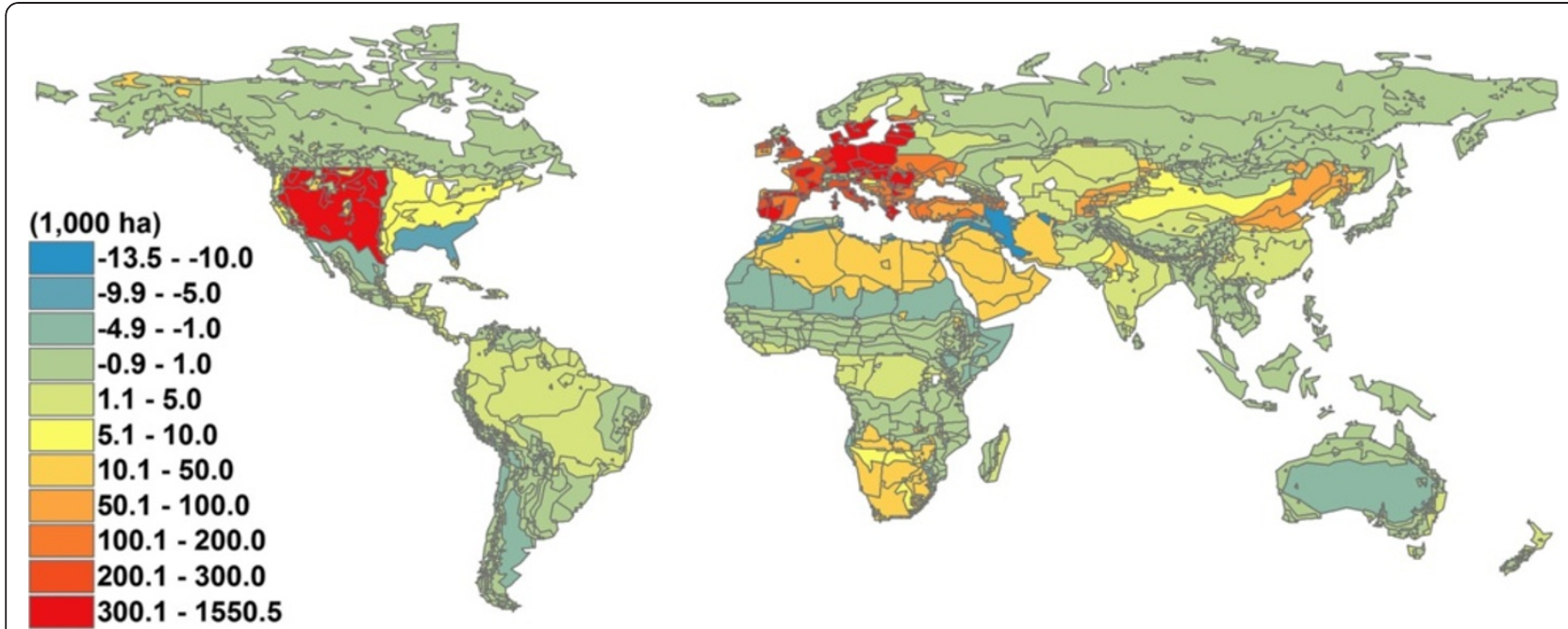

Figure 3 Irrigated cropland cover change, without irrigation constraint.

AEZ10, and AEZ11 (which cover the Midwest) are higher than this figure by $30.4 \%, 40.2 \%$, and $58.2 \%$, respectively. Therefore, any deforestation in these Midwest AEZs would induce larger land use emissions than deforestation in the West (AEZ7).

Figure 8 represents land use emission factors for pasture conversion to croplands. In general, the land emission factors of pasture areas are smaller than the forest areas in the same region/AEZ. For example, the pasture land emission factor of US AEZ7 is about $101 \mathrm{Mg} \mathrm{CO} /$ ha. This is about one-fourth of the forest conversion emission factor in this AEZ.

The model developed by Plevin et al. [41] takes GTAP land use changes and calculates land use emissions in grams of $\mathrm{CO}_{2}$ equivalent per megajoule $\left(\mathrm{g} \mathrm{CO}_{2} \mathrm{e} / \mathrm{MJ}\right)$ of produced biofuel (ethanol in this case). The land use emissions calculated for the three simulation results are shown in Table 5. This table indicates that increasing US ethanol production from its 2001 level to 56.78 billion liters causes about $35.6 \mathrm{~g} \mathrm{CO}_{2} \mathrm{e} / \mathrm{MJ}$ emissions if there is no irrigation constraint across the world. Factoring in the physical limitations on irrigation expansion increases the land-based emissions to $45.4 \mathrm{~g} \mathrm{CO}_{2} \mathrm{e} / \mathrm{MJ}$. This means that the physical water scarcity adds $27.5 \%$ to the emissions due to land use changes induced by ethanol expansion. As shown in Table 5, the constrained case also generates $27.5 \%$ more emissions compared to the case wherein we ignore irrigation altogether. This means that earlier studies, which failed to distinguish rainfed from irrigated lands, likely underestimated induced land use emissions due to ethanol production by more than one quarter.

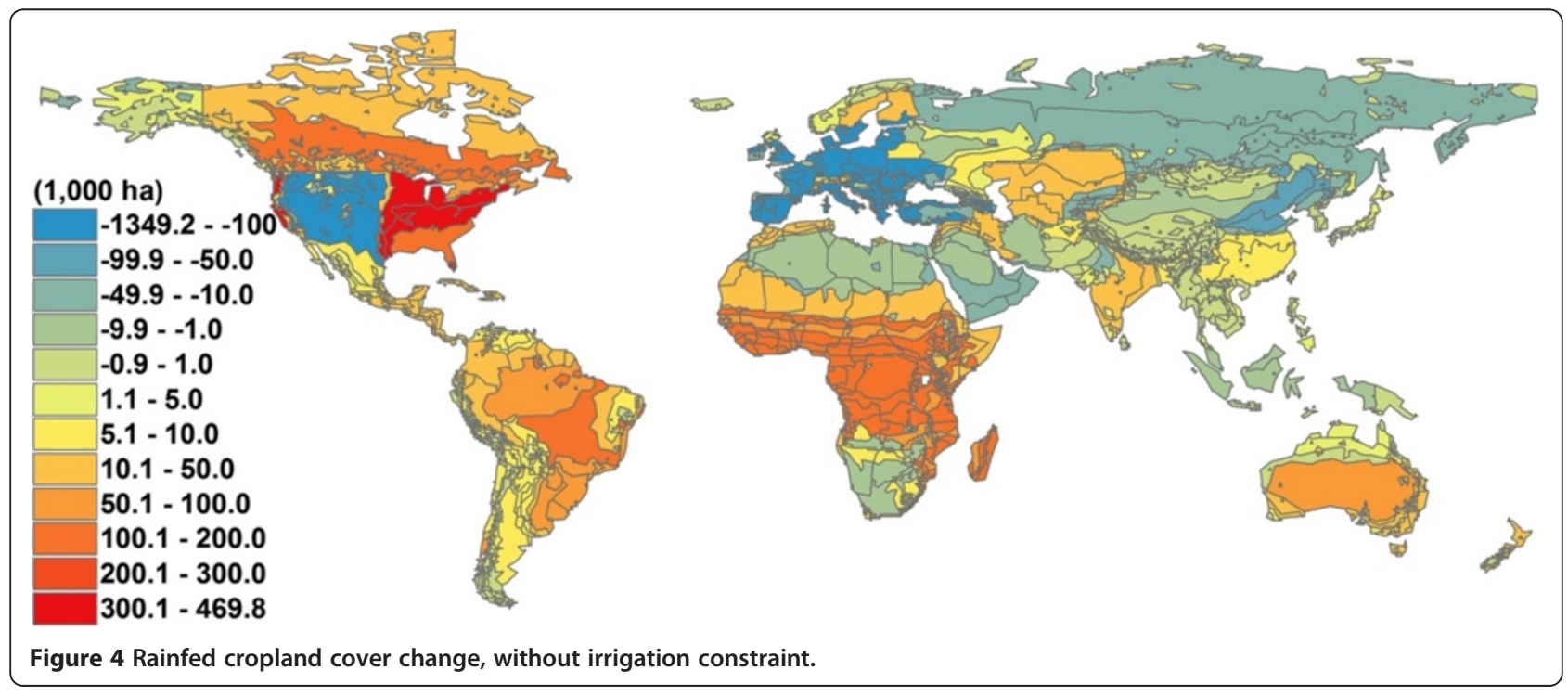




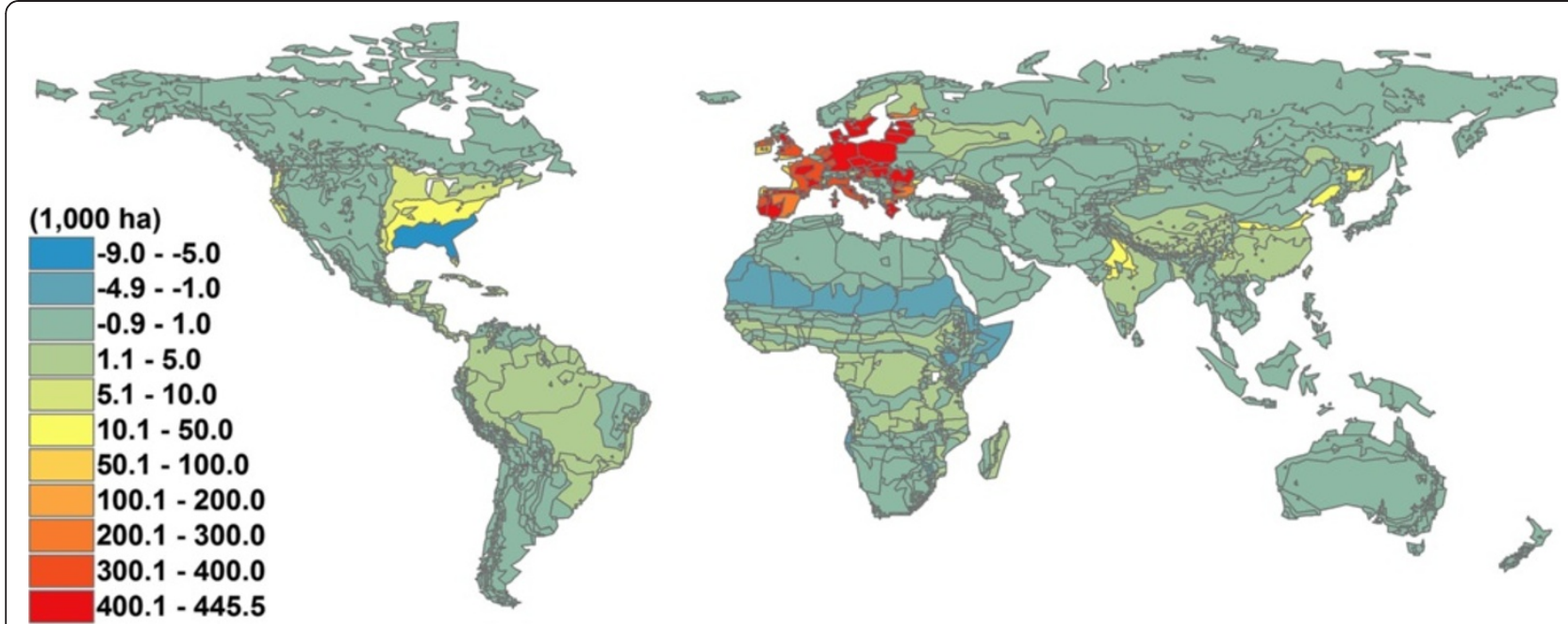

Figure 5 Irrigated cropland cover change, with irrigation constraint.

\section{Conclusions}

In recent years, numerous studies have examined the global land use changes and consequent emissions due to biofuel expansion across the world. These studies have effectively ignored the distinction between rainfed and irrigated lands. This paper develops a new general equilibrium framework which, unlike the existing global CGE models, disaggregates irrigated and rainfed cropping industries to examine the role of potential irrigation constraints in biofuel-induced land use changes. Application of this framework to the problem of biofuelinduced emissions from land use change shows that models which ignore the role of irrigation and mingled irrigated and rainfed areas tend to systematically underestimate the induced land use changes due to the US ethanol program. By ignoring the role of irrigation and the presence of constraints on its expansion in some parts of the world, previous studies have underestimated the induced land use emissions due to ethanol production. In particular, previous studies built based on the earlier version of the GTAP-BIO model resulted in estimates of land-based emissions of ethanol expansion which are too small by about one quarter.

All of the estimated induced land use changes due to biofuels and their associated emissions provided in the literature are subject to significant uncertainties. In this paper, we concluded that by ignoring the role of irrigation, previous studies have underestimated the induced land use emissions due to ethanol production. By incorporating these factors into the estimation process for induced land use emission, we can provide more accurate results. We show that this omission introduces

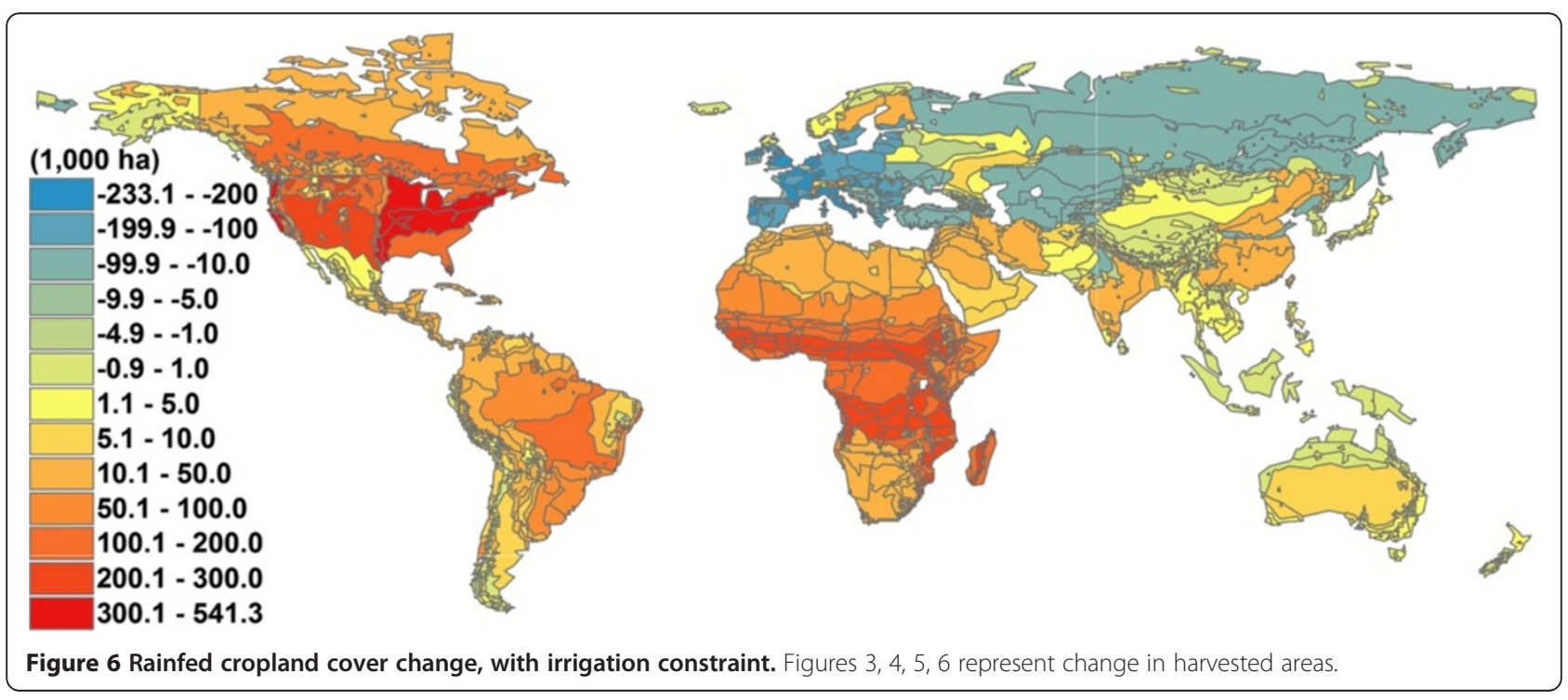




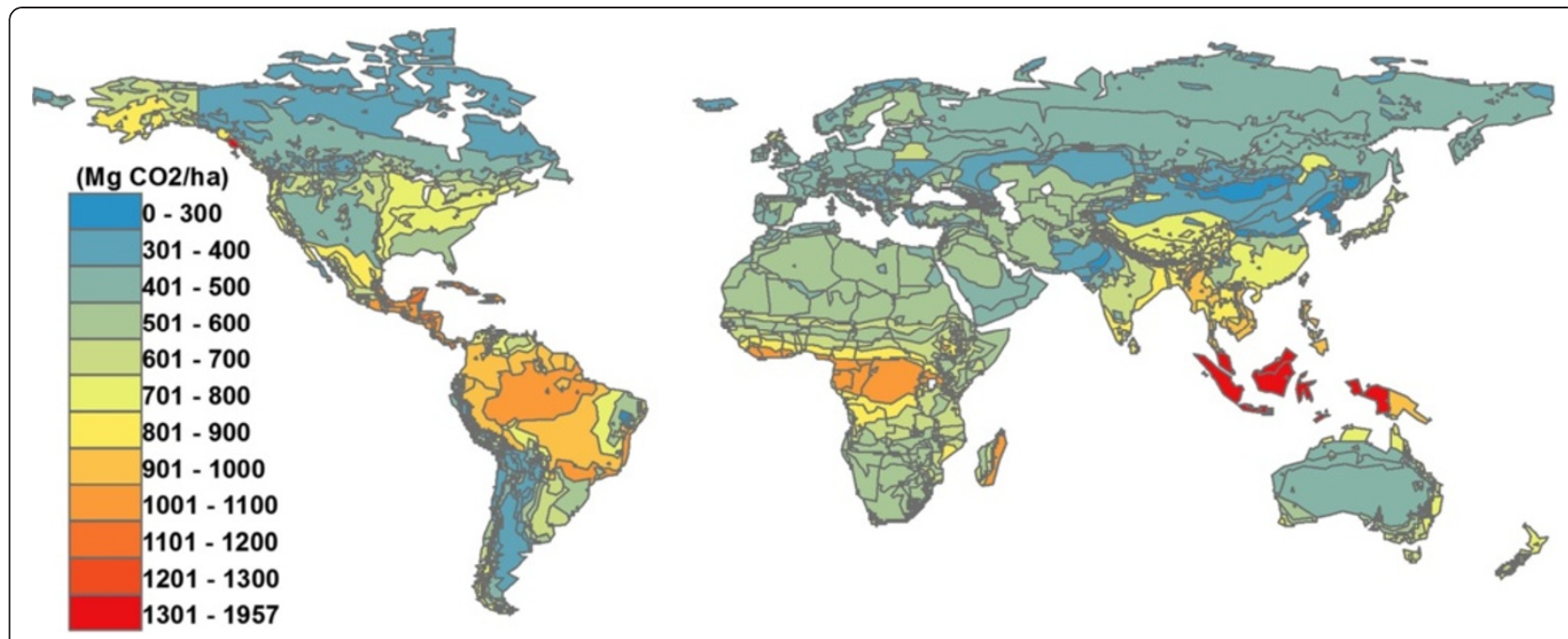

Figure 7 Carbon fluxes ( $\mathrm{Mg} \mathrm{CO}_{2} / \mathrm{ha} /$ year) due to conversion of forest to cropland. (Source: Plevin et al. [41]).

systematic biases in the measurement of the size and pattern of global land use changes and therefore the land use emissions due to production of biofuels.

\section{Endnotes}

To measure the land use consequences of reduction in food consumption due to ethanol production, following Hertel et al. [17], we developed an experiment which assumes food consumption is fixed everywhere across the world in the presence of irrigation constraints. The results indicate that when the irrigation constraints are imposed and food consumption is also fixed, the size of cropland expansion due to corn ethanol production is about 5.2 million hectares, about 0.8 million hectares (or 18.2\%) higher than the corresponding case when food consumption is not fixed. When food consumption is fixed the induced land use emissions are $59.8 \mathrm{~g} \mathrm{CO}_{2} \mathrm{e} /$ $\mathrm{MJ}$ or $31.6 \%$ higher than the corresponding case when food consumption is not fixed. Thus, it is clear that the response of consumers to biofuel expansion is a critical piece of the puzzle.

\section{Appendix}

Global harvested area and crop production by irrigation type

\section{Database modifications}

To enhance the biophysical component of the GTAPBIO-AEZ database, the following steps were followed to introduce crops produced and area harvested by irrigation type. We began with the PSD data at the grid cell

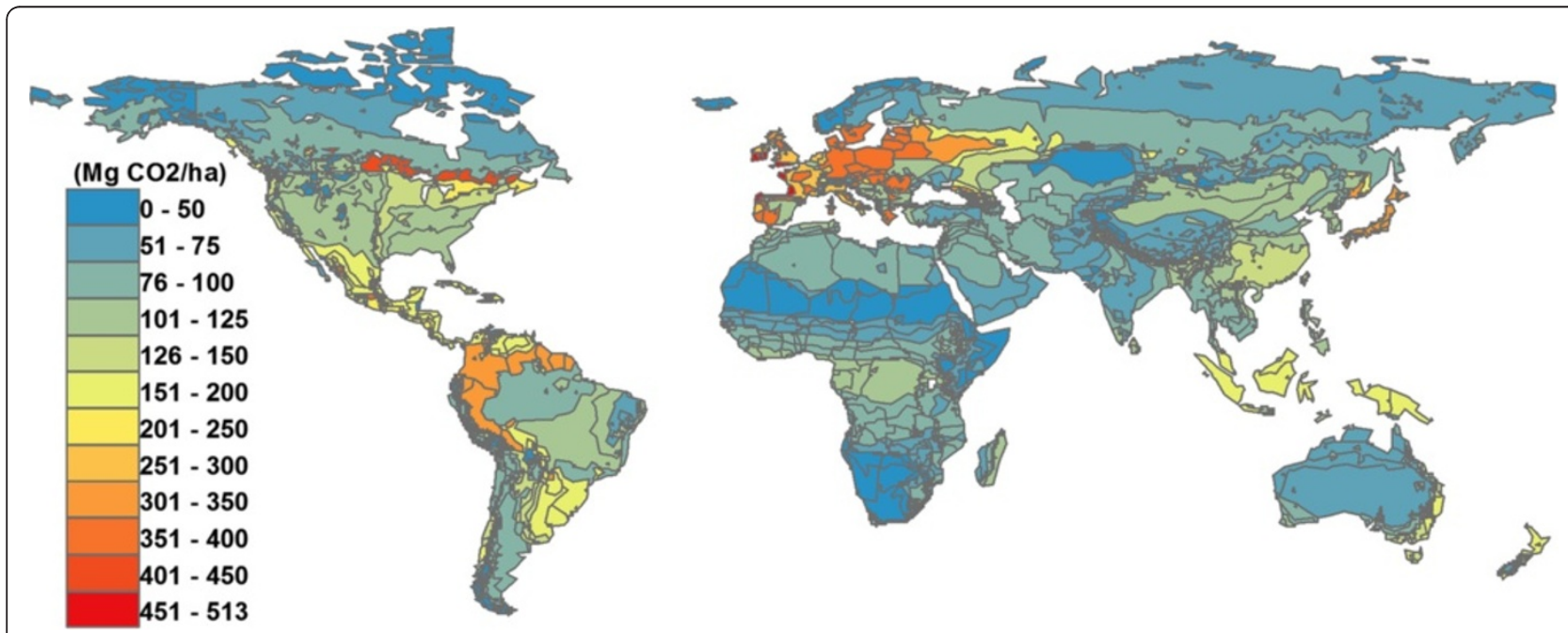

Figure 8 Carbon fluxes $\left(\mathrm{Mg} \mathrm{CO}_{2} / \mathrm{ha} / \mathrm{year}\right)$ due to conversion of pasture to cropland. (Source: Plevin et al. [41]). 
Table 5 Land use emissions due to US ethanol production

\begin{tabular}{lccc}
\hline Simulations & $\begin{array}{c}\text { Ethanol } \\
\text { production } \\
\text { (billion } \\
\text { liters) }\end{array}$ & Annualized ILUC emissions & Deviation from no-irrigation (\%) \\
\cline { 3 - 4 }$(\mathbf{g ~ C O} \mathbf{2} / \mathbf{M J})$ & 35.6 & -0.05 \\
Unconstrained & 50.08 & 35.6 & 0.0 \\
No-irrigation & 50.08 & 45.4 & 27.5 \\
Constrained & 50.08 & & \\
\hline
\end{tabular}

level and computed production by irrigation type using the following equation:

$$
Q_{i j}^{w}=A_{i j}^{w} \times Y_{i j}^{w}
$$

Here, $Q, A$, and $Y$ represent crop quantity, harvested area, and yield. The superscript $w$ denotes irrigation type (with either $w=$ irrigated or $w=$ rainfed), $i$ indicates the crop type with 29 members based on PSD, and $j$ shows the index of grid cell for all grid cells available in the PSD data set. Then, we aggregated PSD gridded harvested area and crop production up to country by AEZ and crop to match the results with the GTAP aggregation scheme of the data set of Monfreda et al. [37]. The GTAP data set aggregates crops into eight categories. The mapping schedule from PDS to GTAP database is presented in Table 6 . Then we used the following relationships to split harvested area and crop production of SAGE/GTAP data into irrigated and rainfed categories:

$$
\begin{aligned}
& Q_{i r z}^{w^{\mathrm{SAGE}}}=\left[\frac{Q_{i r z}^{w^{\mathrm{PSD}}}}{\sum_{w} Q_{i r z}^{w^{\mathrm{PSD}}}}\right] \times Q_{i r z}^{\mathrm{SAGE}} \\
& A_{i r z}^{w^{\mathrm{SAGE}}}=\left[\frac{A_{i r z}^{w^{\mathrm{PSD}}}}{\sum_{w} A_{i r z}^{w^{\mathrm{PSD}}}}\right] \times A_{i r z}^{\mathrm{SAGE}}
\end{aligned}
$$

These two equations serve to share out the quantity produced and area harvested in the SAGE database into irrigated and rainfed components. Specifically, $Q$ and $A$ represent crop quantity and harvested area, $w$ shows the index of irrigation type with two categories of irrigated and rainfed type, $i$ indicates crop type with eight members, $r$ shows the index of the region for all regions in the data set, $z$ is the index of AEZ from 1 to 18, and finally, PSD and SAGE represent their corresponding data sets. Finally, the new data set is aggregated into 19 regions by AEZ according to the regional aggregation level used in this paper. These 19 regions and their members are shown in Table 7.

The main aspects of the obtained database are examined in the rest of this 'Appendix'. Tables 8 and 9 summarize the new data set at an aggregated regional level as presented in Table 7. In these tables, we sum harvested areas and crop outputs over all types of crops and all AEZs. In this newly constructed database, about
$23 \%$ of the global harvested area is irrigated, while global irrigated lands account for about 38\% of global agricultural outputs (measured by weight). This indicates that irrigated lands are more productive versus rainfed lands. The global average yields for irrigated and rainfed areas are about 10.8 and 5.3 metric ton/ha.

To understand the role of irrigation in crop produc-

\begin{tabular}{|c|c|}
\hline PSD crop categories & GTAP/SAGE crop categories \\
\hline Wheat & wht \\
\hline Maize for grain & gro \\
\hline Rice & $\mathrm{pdr}$ \\
\hline Barley & gro \\
\hline Rye for grain & gro \\
\hline Millet & gro \\
\hline Sorghum for grain & gro \\
\hline Soybeans & osd \\
\hline Sunflower & osd \\
\hline Potatoes & $v-f$ \\
\hline Cassava & $v-f$ \\
\hline Sugar cane & $c-b$ \\
\hline Sugar beets & $c-b$ \\
\hline Oil palm & osd \\
\hline Rapeseed/canola & osd \\
\hline Groundnuts/peanuts & osd \\
\hline Pulses & $v-f$ \\
\hline Citrus & $v-f$ \\
\hline Date palm & $v-f$ \\
\hline Grapes/vine & $v-f$ \\
\hline Cotton & $\mathrm{pfb}$ \\
\hline Cocoa & ocr \\
\hline Coffee & ocr \\
\hline Others perennial & ocr \\
\hline Managed grassland/pasture & ocr \\
\hline Others annual & ocr \\
\hline Maize, forage & ocr \\
\hline Rye, forage & ocr \\
\hline Sorghum, forage & ocr \\
\hline
\end{tabular}
tion, we review the new database from different angles.

\section{Table 6 PSD and SAGE crop categories}


Table 7 GTAP regions and their members

\begin{tabular}{|c|c|c|}
\hline Region & Description & Corresponding countries in GTAP \\
\hline$\overline{U S A}$ & United States of America & usa \\
\hline EU27 & European Union 27 & $\begin{array}{l}\text { aut, bel, bgr, cyp, cze, deu, dnk, esp, est, fin, fra, gbr, grc, } \\
\text { hun, irl, ita, Itu, lux, Iva, mlt, nld, pol, prt, rom, svk, svn, swe }\end{array}$ \\
\hline Brazil & Brazil & bra \\
\hline Canada & Canada & can \\
\hline Japan & Japan & jpn \\
\hline China & China and Hong Kong & chn, hkg \\
\hline India & India & ind \\
\hline Central America & Central and Caribbean Americas & mex, xna, xca, xfa, xcb \\
\hline South America & South and other Americas & col, per, ven, xap, arg, chl, ury, xsm \\
\hline East Asia & East Asia & kor, twn, xea \\
\hline Malaysia-Indonesia & Malaysia and Indonesia & ind, mys \\
\hline Rest of Southeast Asia & Rest of South East Asia & phl, sgp, tha, vnm, xse \\
\hline Rest of South Asia & Rest of South Asia & bgd, lka, pak, xsa \\
\hline Russia & Russia & rus \\
\hline E-Europe-RFSU & Other East Europe and rest of former Soviet Union & xer, alb, hrv, xsu, tur \\
\hline Other European regions & Rest of European countries & che, xef \\
\hline M-East-N-Africa & Middle Eastern and North Africa & xme, mar, tun, xnf \\
\hline Sub-Saharan Africa & Sub-Saharan Africa & bwa, zaf, xsc, mwi, moz, tza, zmb, zwe, xsd, mdg, uga, xss \\
\hline Oceania & Oceania countries & aus, nzl, xoc \\
\hline
\end{tabular}

Table 8 Geographical distribution of land by irrigation type

\begin{tabular}{|c|c|c|c|c|c|c|c|c|c|}
\hline \multirow[t]{2}{*}{ Region } & \multicolumn{3}{|c|}{ Area (million hectares) } & \multicolumn{3}{|c|}{ Distribution by irrigation (\%) } & \multicolumn{3}{|c|}{ Geographical distribution (\%) } \\
\hline & Rainfed & Irrigated & Total & Rainfed & Irrigated & Total & Rainfed & Irrigated & Total \\
\hline USA & 111.1 & 21.0 & 132.0 & 84.1 & 15.9 & 100.0 & 11.3 & 7.2 & 10.3 \\
\hline EU27 & 104.2 & 10.8 & 115.0 & 90.6 & 9.4 & 100.0 & 10.6 & 3.7 & 9.0 \\
\hline Brazil & 45.4 & 3.1 & 48.5 & 93.5 & 6.5 & 100.0 & 4.6 & 1.1 & 3.8 \\
\hline Canada & 34.7 & 0.6 & 35.3 & 98.3 & 1.7 & 100.0 & 3.5 & 0.2 & 2.8 \\
\hline Japan & 1.8 & 2.4 & 4.2 & 42.0 & 58.0 & 100.0 & 0.2 & 0.8 & 0.3 \\
\hline China & 88.8 & 72.1 & 160.9 & 55.2 & 44.8 & 100.0 & 9.0 & 24.6 & 12.6 \\
\hline India & 114.2 & 68.0 & 182.2 & 62.7 & 37.3 & 100.0 & 11.6 & 23.2 & 14.3 \\
\hline Central America & 19.4 & 8.2 & 27.6 & 70.1 & 29.9 & 100.0 & 2.0 & 2.8 & 2.2 \\
\hline South America & 43.5 & 5.1 & 48.6 & 89.4 & 10.6 & 100.0 & 4.4 & 1.8 & 3.8 \\
\hline East Asia & 3.0 & 2.1 & 5.0 & 59.1 & 40.9 & 100.0 & 0.3 & 0.7 & 0.4 \\
\hline Malaysia-Indonesia & 28.5 & 7.1 & 35.6 & 80.0 & 20.0 & 100.0 & 2.9 & 2.4 & 2.8 \\
\hline Rest of Southeast Asia & 44.2 & 16.4 & 60.6 & 73.0 & 27.0 & 100.0 & 4.5 & 5.6 & 4.7 \\
\hline Rest of South Asia & 18.7 & 27.1 & 45.8 & 40.8 & 59.2 & 100.0 & 1.9 & 9.2 & 3.6 \\
\hline Russia & 72.9 & 3.6 & 76.5 & 95.3 & 4.7 & 100.0 & 7.4 & 1.2 & 6.0 \\
\hline E-Europe-RFSU & 75.3 & 13.6 & 88.9 & 84.8 & 15.2 & 100.0 & 7.7 & 4.6 & 7.0 \\
\hline Other European regions & 1.0 & 0.1 & 1.1 & 95.3 & 4.7 & 100.0 & 0.1 & 0.0 & 0.1 \\
\hline M-East-N-Africa & 21.1 & 18.9 & 40.0 & 52.7 & 47.3 & 100.0 & 2.1 & 6.5 & 3.1 \\
\hline Sub-Saharan Africa & 131.0 & 4.9 & 135.9 & 96.4 & 3.6 & 100.0 & 13.3 & 1.7 & 10.7 \\
\hline Oceania & 24.2 & 8.0 & 32.1 & 75.2 & 24.8 & 100.0 & 2.5 & 2.7 & 2.5 \\
\hline Total & 982.8 & 293.1 & 1275.9 & 77.0 & 23.0 & 100.0 & 100.0 & 100.0 & 100.0 \\
\hline
\end{tabular}


Table 9 Geographical distribution of crop production by irrigation type

\begin{tabular}{|c|c|c|c|c|c|c|c|c|c|}
\hline \multirow[t]{2}{*}{ Region } & \multicolumn{3}{|c|}{ Production (million metric tons) } & \multicolumn{3}{|c|}{ Distribution by irrigation (\%) } & \multicolumn{3}{|c|}{ Geographical distribution (\%) } \\
\hline & Rainfed & Irrigated & Total & Rainfed & Irrigated & Total & Rainfed & Irrigated & Total \\
\hline USA & 839.7 & 417.2 & 1256.8 & 66.8 & 33.2 & 100.0 & 16.2 & 13.1 & 15.0 \\
\hline EU27 & 1064.5 & 210.9 & 1275.3 & 83.5 & 16.5 & 100.0 & 20.5 & 6.6 & 15.2 \\
\hline Brazil & 261.1 & 245.0 & 506.1 & 51.6 & 48.4 & 100.0 & 5.0 & 7.7 & 6.0 \\
\hline Canada & 165.0 & 7.5 & 172.5 & 95.7 & 4.3 & 100.0 & 3.2 & 0.2 & 2.1 \\
\hline Japan & 50.9 & 23.4 & 74.3 & 68.5 & 31.5 & 100.0 & 1.0 & 0.7 & 0.9 \\
\hline China & 696.4 & 507.8 & 1204.1 & 57.8 & 42.2 & 100.0 & 13.4 & 16.0 & 14.4 \\
\hline India & 283.4 & 509.3 & 792.7 & 35.7 & 64.3 & 100.0 & 5.5 & 16.0 & 9.5 \\
\hline Central America & 63.2 & 186.6 & 249.7 & 25.3 & 74.7 & 100.0 & 1.2 & 5.9 & 3.0 \\
\hline South America & 286.6 & 118.0 & 404.6 & 70.8 & 29.2 & 100.0 & 5.5 & 3.7 & 4.8 \\
\hline East Asia & 20.5 & 14.5 & 34.9 & 58.6 & 41.4 & 100.0 & 0.4 & 0.5 & 0.4 \\
\hline Malaysia-Indonesia & 191.1 & 48.0 & 239.1 & 79.9 & 20.1 & 100.0 & 3.7 & 1.5 & 2.9 \\
\hline Rest of Southeast Asia & 179.4 & 151.6 & 331.0 & 54.2 & 45.8 & 100.0 & 3.5 & 4.8 & 4.0 \\
\hline Rest of South Asia & 46.8 & 137.6 & 184.5 & 25.4 & 74.6 & 100.0 & 0.9 & 4.3 & 2.2 \\
\hline Russia & 310.2 & 32.8 & 343.0 & 90.4 & 9.6 & 100.0 & 6.0 & 1.0 & 4.1 \\
\hline E-Europe-RFSU & 268.5 & 118.1 & 386.6 & 69.5 & 30.5 & 100.0 & 5.2 & 3.7 & 4.6 \\
\hline Other European regions & 18.7 & 1.0 & 19.7 & 95.0 & 5.0 & 100.0 & 0.4 & 0.0 & 0.2 \\
\hline M-East-N-Africa & 47.2 & 212.7 & 259.8 & 18.1 & 81.9 & 100.0 & 0.9 & 6.7 & 3.1 \\
\hline Sub-Saharan Africa & 305.4 & 59.5 & 365.0 & 83.7 & 16.3 & 100.0 & 5.9 & 1.9 & 4.4 \\
\hline Oceania & 94.6 & 173.3 & 267.9 & 35.3 & 64.7 & 100.0 & 1.8 & 5.5 & 3.2 \\
\hline Total & 5193.0 & 3174.6 & 8367.6 & 62.1 & 37.9 & 100.0 & 100.0 & 100.0 & 100.0 \\
\hline
\end{tabular}

First, consider the geographical distribution of harvested area and crop production regardless of irrigation type. Table 8 shows that about $57 \%$ of global harvested areas belong to India (14.3\%), China (12.6\%), Sub-Saharan Africa (10.7\%), USA (10.3\%), and EU (9\%) regions.
Table 9 represents global distribution of crop production. This table indicates that the shares of India and Sub-Saharan Africa in global crop production are about $9.5 \%$ and $4.4 \%$, respectively. These figures are less than the shares of these regions in global harvested area. The

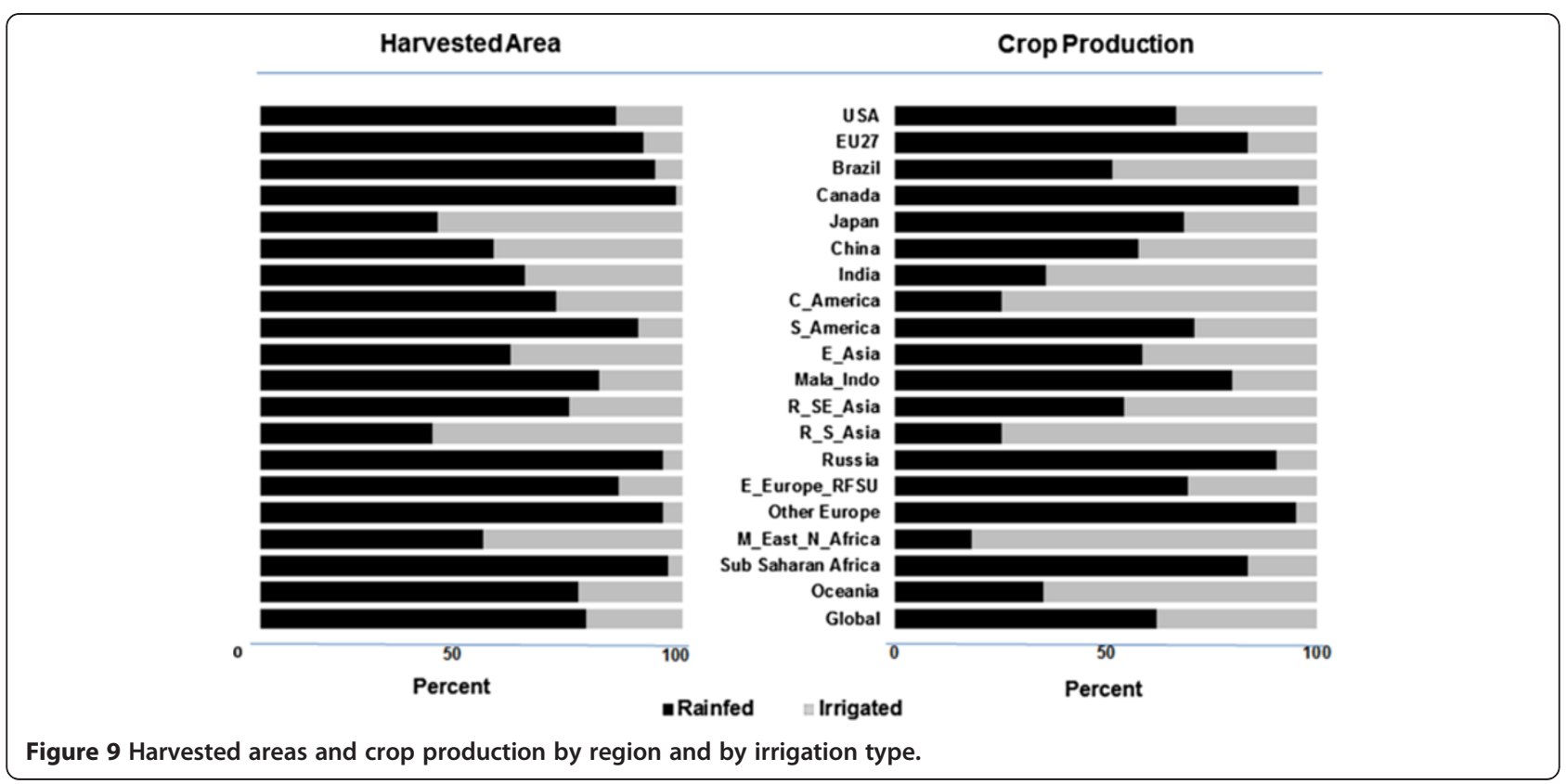




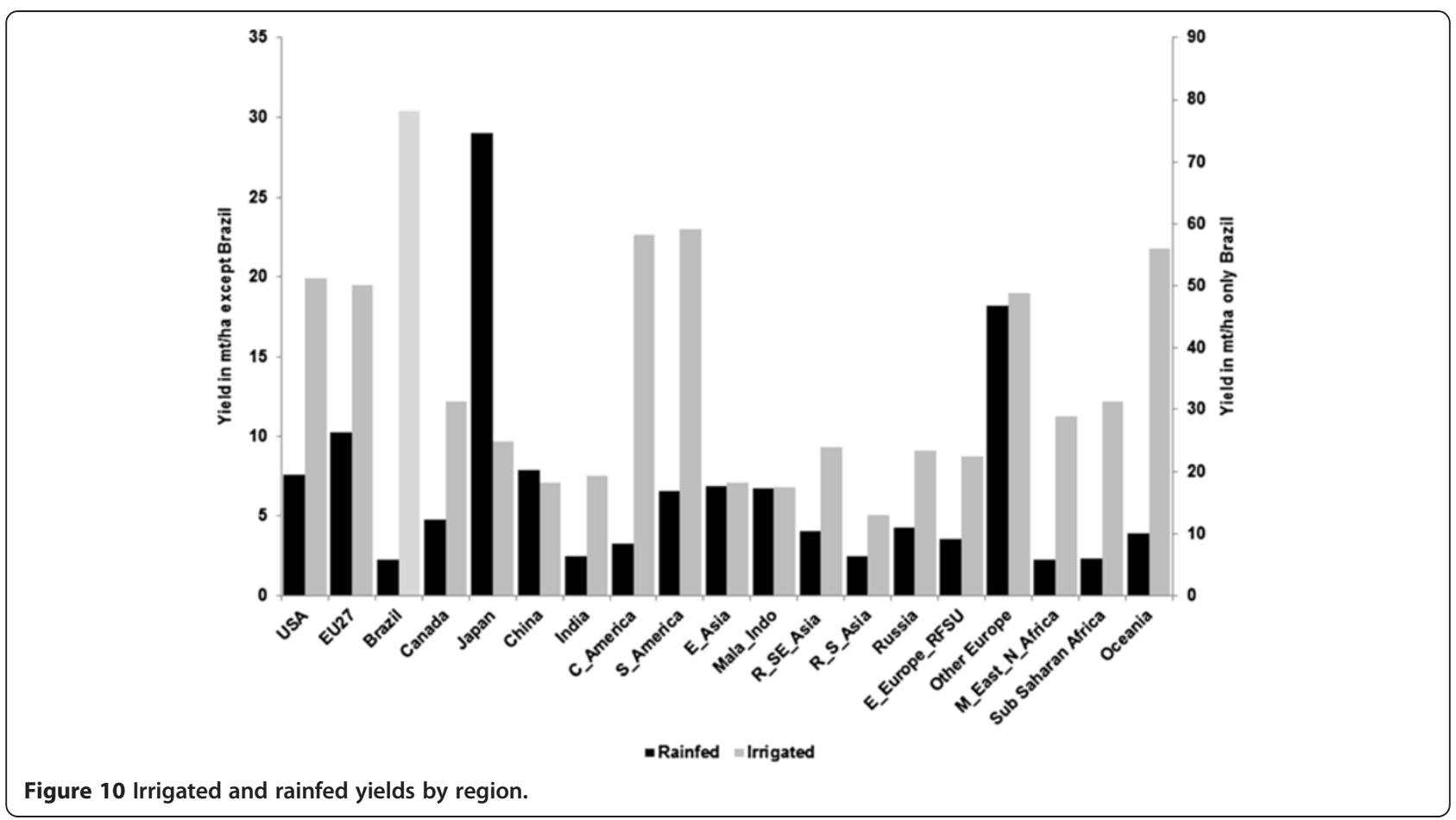

share of China in global crop production is about $14.4 \%$, moderately higher than its share in global harvested area. However, the shares of USA and EU in global crop production are about $15 \%$ and $15.2 \%$, which are considerably higher than their shares in global harvested area.
This indicates that the US and EU croplands are physically more productive compared to the world average productivity of land.

Now consider the global distributions of harvested area and crop production by irrigation type. Table 8
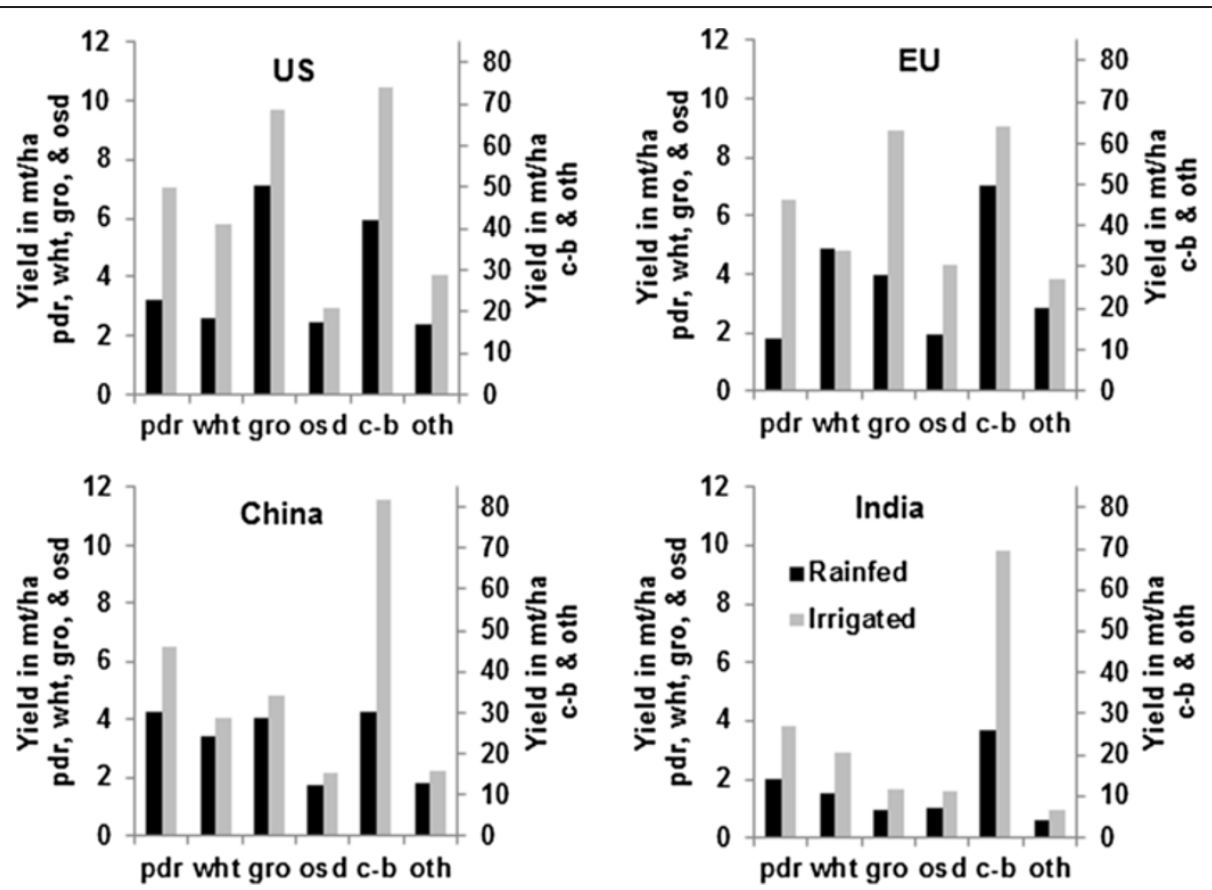

Figure 11 Irrigated and rainfed yields by crop types for selected regions. In this figure, pdr, wht, gro, osd, c-b, and oth represent paddy rice, wheat, coarse grains, oilseeds, sugar crops, and other crops. 


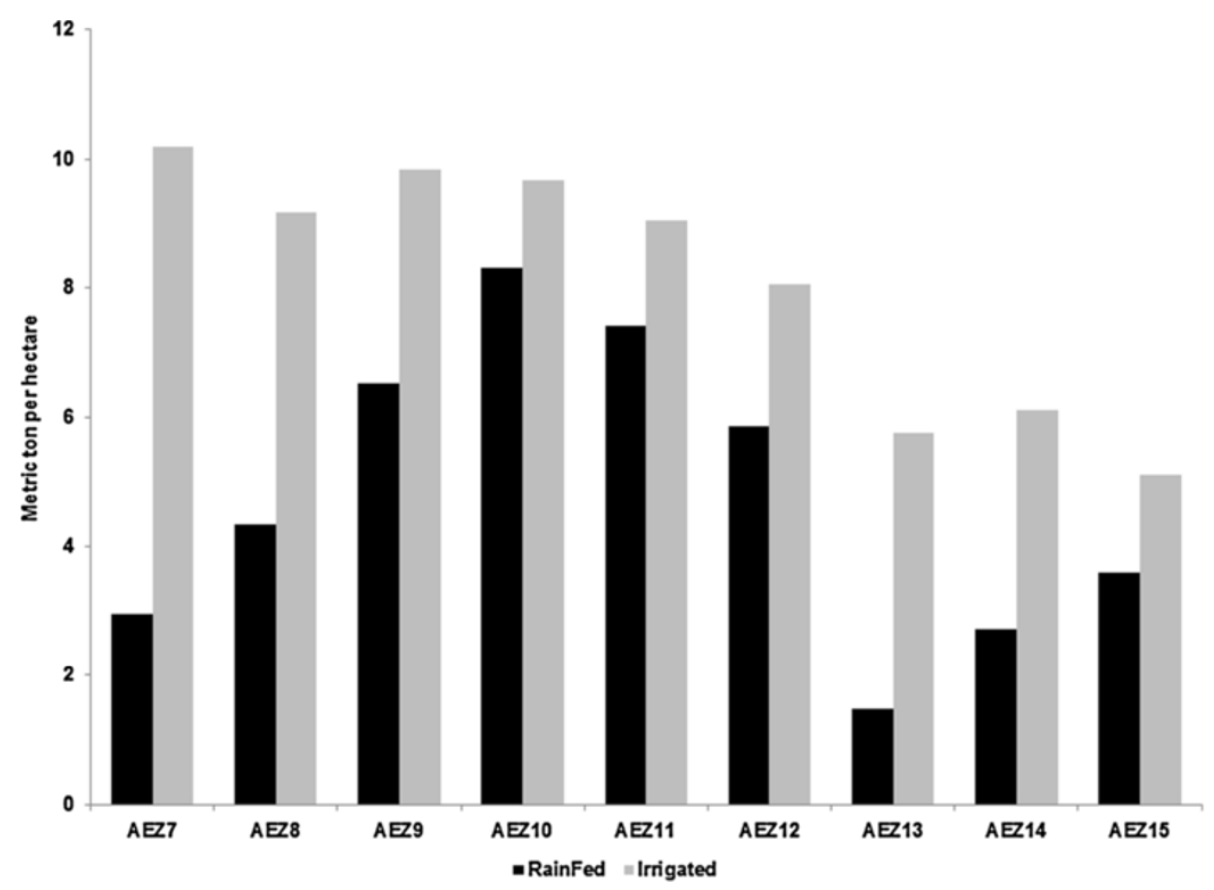

Figure 12 US coarse grain yields by irrigation type and AEZ.

indicates that about $60.3 \%$ of global rainfed harvested areas belong to Sub-Saharan Africa (13.3\%), India (11.6\%), USA (11.3\%), EU (10.6\%), China (9\%) and Brazil (4.6\%). Table 9 shows the global distribution of the rainfed crop production. It indicates that the shares of Sub-Saharan Africa and India in the rainfed crop production are about $5.9 \%$ and $5.5 \%$, respectively. These figures are significantly lower than their corresponding shares in the harvested rainfed areas. However, the shares of USA and EU in the global rainfed crop production are about $16.2 \%$ and $20.5 \%$, which are significantly larger than their shares in the global rainfed harvested areas. These figures indicate that productivities of the rainfed crops in these two regions (in particular in the EU) are relatively higher than the world average.

Consider now the global distributions of harvested area and crop production for irrigated practices. Table 8 shows that more than $65 \%$ of the global irrigated areas belong to Asian countries and regions, including China (24.6\%), India (23.2\%), and all countries located in East and Southeast Asia (18\%). After these regions, the largest area of irrigated land belongs to the USA, which owns about $7.2 \%$ of the global irrigated areas. On the other hand, Table 9 indicates that China, India, and USA supply about $16 \%, 16 \%$, and $13 \%$ of irrigated crops, respectively. These figures show that, while China and India control about half of the global irrigated areas, they account only for $32 \%$ the global irrigated crops.

We now use Figure 9 to analyze the harvested area and crop production within each region by irrigation type. The left panel of this figure indicates the shares of irrigated and rainfed harvested areas in each region. This panel indicates that agricultural activities in some regions like Canada, Russia, and Sub-Saharan Africa mainly rely on rain. On the other hand, countries located in Asia rely more on irrigation.

The right panel in Figure 9 represents shares of irrigated and rainfed crops in each region. The share of irrigated crop is higher than the share of irrigated land in each region and all regions presented in Figure 9, except for Japan and China. This shows that, in general, irrigated areas are more productive than their counterpart rainfed areas in each region.

To investigate differences in yield between rainfed and irrigated lands, consider Figure 10. This figure shows that irrigated croplands typically have much higher yields than their rainfed counterparts in each region. This figure shows that in Brazil, there is a major difference between the yields of irrigated and rainfed lands. This is due to the fact that irrigated sugarcane provides much better yield than the rainfed counterpart. In preparing Figure 10, we summed up harvested areas and outputs over all types of crops and AEZs. To examine differences between the irrigated and rainfed yields by crops, now consider Figure 11, which shows differences between the irrigated and rainfed yields for six crop categories for the major crop producer countries of USA, EU, China, and India. This figure shows that in all of these countries, irrigated and rainfed yields are different for each and every crop. It also indicates that yields 
are usually higher in the USA for almost all crops, with few exceptions. EU yields for the irrigated oilseeds and the rainfed wheat are higher than other regions. Among these four regions, India has the lowest yields for all six crop categories.

Figure 11 shows that the US rainfed and irrigated national yields are not very different for coarse grains. However, this is clearly a function of compositional effects since, as Figure 12 shows, US rainfed and irrigated coarse grains at the AEZ level are very different. The largest differences between the rainfed and irrigated coarse grains yields arise in the drier AEZs, including AEZ7, AEZ8, AEZ13, and AEZ14, which produce irrigated corn. However, in the Midwest areas where rainfed corn is the dominant crop (mainly AEZ10 and AEZ11), there is no major difference between the irrigated and rainfed yields, suggesting that irrigation in these regions is largely an occasional supplement to normally ample rainfall.

\section{Model modifications}

The GTAP-BIO model is entirely revised to introduce crop industries by irrigation type. In particular, we introduce the following equations into the model to handle production of one homogeneous commodity by two distinct industries (all variables are expressed in percentage change form for ease of interpretation):

$$
p i_{\text {irrigated }_{j}}=p i_{\text {rainfed }_{j}}=p s_{j} \text {, for all } j \in \text { set of crop commodities, }
$$

$$
\begin{aligned}
& p i_{j}=\sum_{k \in \mathrm{top}_{\mathrm{com}}}^{K} S_{j k} \times p f_{j k} \text { for all } j \in \text { cropindustries set, } \\
& q f_{j k}=q i_{j}-\varepsilon\left[p f_{j k}-p i_{j}\right]
\end{aligned}
$$
for all $k \in$ top $_{\text {com }}$ set and all $j \in$ crop industries set,

$$
\begin{aligned}
q o_{c}= & \sum_{w \in \text { irrigated, rainfed }} s h r_{c w} \times q i_{c w} \\
& \text { for all } c \in \text { set of crop commodities }
\end{aligned}
$$

In the above equations, $p i$ and $q i$ represent percent changes in the price and quantity of $j$ at the industry level, and $p s$ and qo represent their corresponding percentage changes at the commodity market level (where there is no distinction made about the method of production). The variables $q f$ and $p f$ stand for percentage changes in prices and quantities of inputs used for crop production at the industry level. Finally, $S_{j k}$ represents the cost share of input $k$ in industry $j, \varepsilon$ is the elasticity of substitution among intermediate inputs, and $\mathrm{shr}_{c w}$ is the share of crop $c$ supply by irrigation type $w$.
Equation 4 ensures that irrigated and rainfed industries which produce the same crop (e.g., wheat) will receive the same price and that the prices at the industry and commodity levels are the same. Equation 5 is the zero profit condition for each crop industry. Equation 6 represents the demand for intermediate input $k$ in crop industry $j$, and finally, Equation 7 ensures market clearing condition for each crop.

\section{Irrigated and rainfed input cost shares}

We now demonstrate why the input cost shares of the irrigated and rainfed industries which produce the same crop should be the same given our other assumptions. Consider two industries of irrigated wheat (shown with $J=1$ ) and rainfed wheat (shown with $J=$ 2 ). We assume that the prices of irrigated wheat and rainfed wheat are same (i.e., $P S_{1}=P S_{2}=P S_{\text {wheat }}$, where $P S$ represent price level) and also that the input/out ratios are the same for non-land inputs (i.e., $\frac{Q F_{1 k \neq \text { land }}}{Q S_{1}}=$ $\frac{Q F_{2 k \neq l a n d}}{Q S_{2}}$, where $Q F$ and $Q S$ represent input and output levels, respectively), and both industries pay the same price for a given input (i.e. $P F_{1 k} \neq$ land $=P F_{2 k} \neq$ land $=$ $P F_{k} \neq$ land, where $\mathrm{PF}$ represent input price level). This implies that:

$$
\begin{aligned}
S_{1 k} & =\frac{P F_{k}}{P S_{\text {wheat }}} \frac{Q F_{1 k}}{Q S_{1}}=\frac{P F_{k}}{P S_{\text {wheat }}} \frac{Q F_{2 k}}{Q S_{2}} \\
& =S_{2 k} \text { for all } k \in \text { non }- \text { land inputs. }
\end{aligned}
$$

Equation 8 leads to:

$$
\sum_{k \neq \text { land }}^{K} S_{1 k}=\sum_{k \neq \text { land }}^{K} S_{2 k}
$$

Since the cost shares of each industry must be summed to one, we then can conclude that

$$
\begin{aligned}
S_{1 \text { land }} & =\frac{P F_{1 \text { land }}}{P S_{\text {wheat }}} \frac{Q F_{1 \text { land }}}{Q S_{1}}=\frac{P F_{2 \text { land }}}{P S_{\text {wheat }}} \frac{Q F_{2 \text { land }}}{Q S_{2}} \\
& =S_{\text {2land }}
\end{aligned}
$$

While the cost shares in irrigated wheat and rainfed wheat are identical, this does not mean that the land rent per hectare is the same. Indeed, since output per unit of land is higher for irrigated wheat, then we conclude that the land rent per unit of irrigated land (including the net contribution of water) should be higher than the land rent per unit of rainfed land.

\section{Abbreviations}

AEZ: Agro-ecological zone; CGE: Computable general equilibrium; GTAPBIO: Global Trade Analysis Project model with Biofuels; ILUC: Indirect land use change; IWMI: International Water Management Institute; PE: Partial equilibrium.

\section{Competing interests}

The authors declare that they have no competing interests. 


\section{Authors' contributions}

FT and TH jointly developed the theoretical foundation, carried out the main developments, and modified the implemented model with JL's contributions. FT and $\mathrm{J}$ developed the database with TH's collaboration. All authors read and approved the final manuscript.

\section{Acknowledgments}

We are deeply indebted to Ximing Cai for his contributions to this work. We had valuable discussions and meetings with him that significantly improved the quality of this work. We would like to thank Stefan Siebert for providing the data on global cropland and crop production by irrigation type which made this research possible. We are also indebted to two anonymous referees of the Journal of Energy, Sustainability, and Society for their constructive and detailed comments. This research is partially funded by grants from the USDA and DOE. Hertel acknowledges the sabbatical support from the US DOE, Office of Science, Office of Biological and Environmental Research, Integrated Assessment Research Program, grant no. DE-SC005171.

Received: 10 October 2012 Accepted: 30 January 2013

Published: 28 February 2013

\section{References}

1. Gurgel A, Reilly J, Paltsev S (2007) Potential land use implications of a global biofuels industry. J Agr Food Ind Organ 5(2), Article 9

2. Searchinger T, Heimlich R, Houghton R, Dong F, Elobeid A, Fabiosa J, Tokgoz S, Hayes D, Yu T (2008) Use of U.S. Croplands for biofuels increases greenhouse gases through emissions from land-use change. Science 319 (5867):1238-1240

3. Fabiosa J, Beghin J, Dong F, Elobeid A, Tokgoz S, Yu T (2010) Land allocation effects of the global ethanol surge: predictions from the international FAPRI model. Land Econ 86(4):687-706

4. Hertel T. (2010) The global supply and demand for agricultural land in 2050: A perfect storm in the making? American Journal of Agricultural Economics 93(2):259-275

5. Taheripour F, Hertel T, Tyner W, Bechman J, Birur D (2010) Biofuels and their by-products: global economic and environmental implications. Biomass Bioenerg 34(3):278-289

6. Tyner W, Taheripour F, Zhuang Q, Birur D, Baldos U (2010) Land use changes and consequent $\mathrm{CO}_{2}$ emissions due to U.S. corn ethanol production: a comprehensive analysis. Department of Agricultural Economics, Purdue University, West Lafayette, USA

7. Taheripour F, Hertel T, Tyner W (2011) Implications of biofuels mandates for the global livestock industry: a computable general equilibrium analysis. Agr Econ 42(3):325-342

8. Portmann T, Siebert S, Döll P (2010) MIRCA2000-global monthly irrigated and rainfed crop areas around the year 2000: a new high-resolution data set for agricultural and hydrological modeling. Global Biogeochem Cy 24: GB1011.

9. Addams L, Boccaletti G, Kerlin M, Stuchtey M (2009) Charting our water future: economic frameworks to inform decision-making. McKinsey \& Company, New York, USA

10. Cai X, Rosegrant M (2002) Global water demand and supply projections, Part 1: a modeling approach. Water Int 27(2):159-169

11. Rockström J, Lannerstad M, Falkenmark M (2007) Assessing the water challenge of a new green revolution in developing countries. P Natl Acad Sci USA 104(15):6253-6260

12. Taheripour F, Birur D, Hertel T, Tyner W (2007) Introducing liquid biofuels into the GTAP database, GTAP Research Memorandum No. 11. GTAP, Purdue University, West Lafayette, USA

13. Calzadilla A, Rehdanz K, Tol R (2011) The GTAP-W model: accounting for water use in agriculture. Kiel Working Papers No. 1745. Kiel Institute for the World Economy, Germany

14. Tokgoz S, Elobeid A, Fabiosa JF, Hayes DJ, Babcock BA, Yu T, Dong F, Hart CE, Beghin JC (2007) Emerging biofuels: outlook of effects on U.S. grain, oilseed, and livestock markets. Staff Report 07-SR 101, Center for Agricultural and Rural Development, lowa State University, USA

15. Kammen DM, Farrell AE, Plevin RJ, Jones AD, Delucchi MA, Nemet GF (2007) Energy and greenhouse impacts of biofuels: a framework for analysis. Discussion paper, Joint Transport Research Centre

16. Fargione J, Hill J, Tilman D, Polasky S, Hawthorne P (2008) Land clearing and the biofuel carbon debt. Science 319(5867):1235-1238
17. Hertel T, Golub A, Jones A, O'Hare M, Pelvin R, Kammen D (2010) Effects of U.S. maize ethanol on global land use and greenhouse gas emissions: estimating market-mediated responses. Bioscience 60(3):223-231

18. Al-Riffai P, Dimaranan B, Laborde D (2010) Global trade and environmental impact study of the EU biofuels mandate. International Food Policy Research Institute. Washington, DC

19. EPA (2010) Renewable fuel standard program (RFS2) regulatory impact analysis. United States Environmental Protection Agency. Washington, DC

20. Laborde D (2011) Assessing the land use change consequences of European biofuels policies. International Food Policy Research Institute. Washington, DC

21. Timilsina G, Beghin J, Mensbrugghe D, Mevel S (2012) The impacts of biofuels targets on land-use change and food supply: a global CGE assessment. Agr Econ 43(3):315-332

22. Keeney R, Hertel T (2009) Indirect land use impacts of us biofuels policies: the importance of acreage, yield and bilateral trade responses. Am J Agr Econ 91(4):895-909

23. Berry S (2011) Biofuels policy and the empirical inputs to GTAP models. Working paper, California Air Resource Board, CA, USA

24. Villoria NB, Hertel TW (2011) Geography matters: international trade patterns and the indirect land use effects of biofuels. Am J Agr Econ 93(4):919-935

25. Wicke B, Verweij P, Meijl H, Vuuren D, Faaij A (2012) Indirect land use changes: review of existing models and strategies for mitigation. Biofuels 3(1):87-100

26. Fraiture C, Giordano M, Liao Y (2008) Biofuels and implications for agricultural water use: blue impacts of green energy. Water Policy 10(1):67-81

27. Hoogeveen J, Faures J, Giessen N (2009) Increased biofuel production in the coming decade: to what extend will it affect global freshwater resources? Irrig Drain 58(S1):S148-S160

28. Dominguez-Faus R, Powers S, Burken J, Alverez J (2009) The water footprint of biofuels: a drink or drive issue? Environ Sci Technol 43(9):3005-3010

29. Hertel TW (1997) Global trade analysis, modeling and applications. Cambridge University Press, Cambridge

30. Hertel T, Rose S, Tol R (2008) Land use in computable general equlibrium models: An overview. GTAP Working Paper No. 39, Purdue University

31. Rosegrant MW, Ringler C, Msangi S, Cline SA, Sulser TB (2005) International model for policy analysis of agricultural commodities and trade (IMPACT-WATER): model description. International Food Policy Research Institute. Washington, DC

32. Kuhn A (2003) From world market to trade flow modelling - the redesigned WATSIM model. Institute of Agricultural Policy, Market Research and Economic Sociology, Bonn

33. Adams DM, Alig RJ, Callaway JM, McCarl BA, Winnett SM (1996) The forest and agriculture sector optimization model (FASOM): model structure and policy applications. Research Paper PNW-RP-495, USDA Forest Service. Pacific Northwest Research Station, Portland, Oregon, p 60p

34. USEPA (2005) Greenhouse gas mitigation potential in U.S. forestry and agriculture, EPA-R-05-006. United States Environmental Protection Agency, Office of Atmospheric Programs, Washington, DC

35. Lotze-Campen H, Muller C, Bondeau A, Jachner A, Popp A, Lucht W (2008) Food demand, productivity growth and the spatial distribution of land and water use: a global modeling approach. Agr Econ 39(3):325-338

36. Schmitz C, Biewald A, Lotze-Campen H, Popp A, Dietrich J, Bodirsky B, Krause M, Weindl I (2012) Trading more food: implications for land use, greenhouse gas emissions, and the food system. Global Environ Chang 22(1):189-209

37. Monfreda C, Ramankutty N, Foley J (2008) Farming the planet: 2. Geographic distribution of crop areas, yields, physiological types, and net primary production in the year 2000. Global Biogeochem Cy 22:GB1022.

38. Alexandratos N, Bruinsma J (2012) World agriculture towards 2030/2050: the 2012 revision. ESA working paper no. 12-03. Global Perspective Studies Team, FAO Agricultural Development Economics Division, Rome, Italy

39. Horridge M (2005) SplitCom: programs to disaggregate a GTAP sector. Monash University, Melbourne, Centre of Policy Studies

40. Smakhtin V (2011) Water management in developing world: adapting to increasing variability and changes. Presentation at Stanford University, 13 Oct 2011

41. Plevin R, Gibbs H, Duffy J, Yui S, Yeh S (2011) Agro-ecological zone emission factor model. California Air Resource Board, USA

doi:10.1186/2192-0567-3-4

Cite this article as: Taheripour et al:: The role of irrigation in determining the global land use impacts of biofuels. Energy, Sustainability and Society 2013 3:4. 